\title{
Susceptibility of protein therapeutics to spontaneous chemical modifications by oxidation, cyclization, and elimination reactions
}

\author{
Luigi Grassi $^{1,2} \cdot$ Chiara Cabrele $^{1,2}$ (])
}

Received: 12 May 2019 / Accepted: 7 September 2019 / Published online: 1 October 2019

(c) The Author(s) 2019

\begin{abstract}
Peptides and proteins are preponderantly emerging in the drug market, as shown by the increasing number of biopharmaceutics already approved or under development. Biomolecules like recombinant monoclonal antibodies have high therapeutic efficacy and offer a valuable alternative to small-molecule drugs. However, due to their complex three-dimensional structure and the presence of many functional groups, the occurrence of spontaneous conformational and chemical changes is much higher for peptides and proteins than for small molecules. The characterization of biotherapeutics with modern and sophisticated analytical methods has revealed the presence of contaminants that mainly arise from oxidation- and elimination-prone amino-acid side chains. This review focuses on protein chemical modifications that may take place during storage due to (1) oxidation (methionine, cysteine, histidine, tyrosine, tryptophan, and phenylalanine), (2) intra- and inter-residue cyclization (aspartic and glutamic acid, asparagine, glutamine, $\mathrm{N}$-terminal dipeptidyl motifs), and (3) $\beta$-elimination (serine, threonine, cysteine, cystine) reactions. It also includes some examples of the impact of such modifications on protein structure and function.
\end{abstract}

Keywords Amino acid · Spontaneous posttranslational modification · Oxidation · Cyclization · Elimination · Protein degradation

\section{Introduction}

The market value of peptide and protein drugs has been experiencing a significant expansion, as reflected by the increasing number of approved synthetic peptides and recombinant monoclonal antibodies (mAbs) for the therapy of different types of human health disorders and diseases (Ecker et al. 2015; Lau and Dunn 2018). To this regard, the introduction of a drug into the market implies that all the regulatory requirements in terms of safety and quality have been addressed. In the case of peptides and proteins, which are medium-to-large molecules with high susceptibility to

Handling Editor: J. D. Wade.

Chiara Cabrele

chiara.cabrele@sbg.ac.at

1 Department of Biosciences, Paris Lodron University of Salzburg, Billrothstrasse 11, 5020 Salzburg, Austria

2 Christian Doppler Laboratory for Innovative Tools for Biosimilar Characterization, Paris Lodron University of Salzburg, Hellbrunnerstrasse 34, 5020 Salzburg, Austria a number of spontaneous or enzyme-dependent chemical modifications, the full analytical characterization of the final product as well as the efficient implementation of the socalled quality-by-design concept (Juran 1992) in the manufacturing process are a big challenge.

Enzyme-catalyzed posttranslational modifications (PTMs) of proteins are used by Nature to expand the chemical space beyond the limit set by the 20 encoded amino acids. However, the presence of PTMs (i.e., glycosylation) in recombinant and isolated proteins gives rise to heterogeneous preparations of biotherapeutics. In addition, spontaneous chemical changes may occur due to the inherent reactivity of peptides and proteins. Therefore, the detection and characterization of any modification at the amino-acid side chain and backbone level is crucial for both regulatory compliance and reliability of the drug potency assessment (Wang et al. 2007). To date, the most powerful technique to assess the chemical identity of biotherapeutics is mass spectrometry (MS): for example, 79 out of the 80 biologics license applications electronically submitted to the FDA in the period 2000-2015 provide quality attributes determined by MS, the following being found in more than $50 \%$ of the applications: 
amino-acid sequence, molecular mass, disulfide bonds, glycosylation, N-/C-terminal sequence variants, deamidation, and oxidation (Rogstad et al. 2017).

The most common MS workflows rely on three types of approaches that utilize MS alone or hyphenated MS, like liquid chromatography-MS (LC-MS) or LC-MS/MS (Beck et al. 2013; Berkowitz et al. 2012; Terral et al. 2016; Zhang et al. 2014): (1) top-down (MS fragmentation of the intact protein under native or denaturing conditions), (2) middledown (MS fragmentation of subunits), and (3) bottom-up (MS fragmentation of the peptides obtained by protein digestion) (Lermyte et al. 2019). Each workflow presents advantages and disadvantages: for example, the top-down workflow does not require long protocols to prepare the MS sample, but it suffers from inefficient fragmentation due to the large size of the proteins, especially of mAbs with molecular mass close to $150 \mathrm{kDa}$. This results in incomplete amino-acid sequence coverage, despite the use of sophisticated MS methods such as electron-transfer dissociation (ETD) with quadrupole time-of-flight (qTOF) or orbitrap high-resolution MS (Fornelli et al. 2012; Tsybin et al. 2011), electron-capture dissociation (ECD) with electrospray ionization (ESI) Fourier-transform ion cyclotron resonance (FTICR) MS (Mao et al. 2013), ESI-FTICR-MS coupled to electrochemistry for the online reduction of disulfide bonds (Nicolardi et al. 2014), matrix-assisted-laser-desorptionionization (MALDI) in-source decay (ISD) with FTICR-MS (van der Burgt et al. 2019), combined ECD, and collisionally activated dissociation (CAD) with FTICR-MS (Jin et al. 2019). The middle-down MS workflow allows increasing the sequence coverage significantly, but it requires the partial proteolysis and deglycosylation of the protein: in the case of mAbs, the enzymes IdeS (immunoglobulin-degrading enzyme of Streptococcus pyogenes) (von Pawel-Rammingen et al. 2002) and GingisKHANTM (recombinant gingipain $\mathrm{K}$ from Porphyromonas gingivalis (Okamoto et al. 1996; Scott et al. 1993), commercialized by Genovis AB, Lund, Sweden), which cleave the heavy chain, respectively, below or above the hinge region, as well as glycosidases and sialidases are used to obtain large subunits that are then analyzed under denaturing (Jin et al. 2019; van der Burgt et al. 2019) or native conditions (Wohlschlager et al. 2018). The bottom-up MS workflow is routinely used for sequence determination, but it requires long sample preparation, with the risk of introducing modifications, for example during trypsin digestion, like additional deamidation of asparagineglycine (Asn-Gly) motifs and of N-terminal glutamine (Gln) (Bongers et al. 2000; Krokhin et al. 2006).

Several spontaneous PTMs have been characterized by bottom-up and middle-down protocols: for example, scrambled disulfide bonds in heat-stressed humanized mAb HER2 (human epidermal growth factor receptor 2) have been found by analyzing the tryptic and Lys-C-digested peptides with
LC-ETD/CAD-MS (Wang et al. 2011a). Methionine (Met) oxidation of three different biotherapeutics treated with $\mathrm{H}_{2} \mathrm{O}_{2}$ (the mAbs rituximab and adalimumab, and the IgG1$\mathrm{Fc}$ fusion protein etanercept) has been detected and quantified by applying a middle-down approach with LC-MS analysis (Regl et al. 2017). Furthermore, a systematic study on the stability of IgG1-Fc glycoforms containing 8-12, 5 , or no mannose units under various stress conditions (photoirradiation, oxidation with $\mathrm{H}_{2} \mathrm{O}_{2}, \mathrm{CuCl}_{2}$ /ascorbate, or a freeradical initiator, and long storage at $40{ }^{\circ} \mathrm{C}$ ) has shown by a bottom-up approach that different degradation profiles are obtained, depending on the mannose content and the stress condition: for example, a deamidation product (already detectable in the control) has been found to accumulate faster in the absence than in the presence of mannose units at $40{ }^{\circ} \mathrm{C}$ (Mozziconacci et al. 2016a). Surprisingly, also a tryptophan (Trp) degradation product (glycine hydroperoxide) was already detectable in the control, but after 1 month at $40{ }^{\circ} \mathrm{C}$, it was more abundant in the presence than in the absence of mannose units. Regarding the oxidation stress, the highest amount of oxidized Met was obtained with $\mathrm{H}_{2} \mathrm{O}_{2}$, but only for the high-mannose and no mannose glycoforms, clearly showing that both the stress protocol and the type of glycan may strongly affect the formation of impurities (Mozziconacci et al. 2016a).

It is well recognized that biotherapeutics carry the intrinsic risk of being immunogenic (Büttel et al. 2011; Pineda et al. 2016), a characteristic that is the likely consequence of multiple factors (type of production, impurities, and mode of administration of the drug, as well as patient's conditions) (Pineda et al. 2016) and, thus, difficult to control or even to suppress. Nevertheless, it would be very important, to monitor the drug immunogenicity not only before but also after drug approval, as shown, for example, by the case of the two mAbs adalimumab (Bartelds et al. 2011; Bender et al. 2007) and infliximab (Pascual-Salcedo et al. 2011): rheumatoid arthritis patients long-treated with these two drugs have been found to produce anti-drug Abs negatively affecting the drug response and efficacy. However, immunogenic responses of patients have been reported for several other approved mAbs (Baker et al. 2010; Kuriakose et al. 2016).

As mentioned above, drug impurities may increase the risk of undesired immunogenicity: these also include protein aggregates and PTMs (Baker et al. 2010; Büttel et al. 2011; Krishna and Nadler 2016; Kuriakose et al. 2016). The relationship between PTMs and immunogenic events is well known, although this is especially investigated in the area of autoimmune diseases (e.g., citrullination of myelic basic protein in rheumatoid arthritis, oxidation of insulin in type I diabetes, and deamidation of transglutaminase in celiac disease) (Doyle and Mamula 2012; Eggleton et al. 2008). PTMs may induce changes of the protein structure (Mallagaray et al. 2019), but they might also modify the type of 
antigens generated (Krishna and Nadler 2016; Kuriakose et al. 2016): for example, the presence of an iso-aspartyl (iso-Asp) residue as deamidation product of cytochrome $c$ has led to a different digestion profile with cathepsin D compared to the native protein (Doyle et al. 2007). In addition, mice immunized with an iso-Asp-containing cytochrome $c$ peptide antigen developed Abs cross-reacting with both the iso-Asp-containing peptide and the native protein (Mamula et al. 1999). Two other examples are related to the oxidation of the collagen-like complement component $\mathrm{C} 1 \mathrm{q}$ and collagen type II: in the first one, animal immunization with $\mathrm{Clq}$ treated with $\mathrm{H}_{2} \mathrm{O}_{2}$ generated Abs cross-reacting with unmodified $\mathrm{Clq}$ or with collagen type II, suggesting a role of C1q oxidation (e.g., by reactive oxygen species) in the induction of arthritis (Trinder et al. 1997). In the second one, a collagen type II peptide antigen containing a galactosylated hydroxylysine, as product of lysine oxidation followed by O-glycosylation, has been proposed to be immunodominant in collagen-induced arthritis (Corthay et al. 1998).

All together, these findings clearly indicate the implication of spontaneous PTMs in protein immunogenicity. In the case of biotherapeutics, while it is not possible to avoid their chemical modification in vivo, it is at least possible to control the presence of PTMs in the drug formulations thanks to the impressive advances made especially in MS, as briefly mentioned above.

Being the chemical space of spontaneous modifications of peptides and proteins very broad, only the most common by-products from three types of reactions, which may occur during storage, will be reviewed in the following sections:
(1) oxidation of Met, cysteine (Cys), histidine (His), tyrosine (Tyr), Trp and phenylalanine (Phe), (2) intra- and inter-residue cyclization involving aspartate (Asp), Asn, glutamate (Glu), Gln and N-terminal dipeptidyl motifs, (3) $\beta$-elimination of serine (Ser), threonine (Thr), Cys, and cystine.

\section{Oxidation of sulfur-containing and aromatic amino acids}

\section{Mechanisms generating reactive oxygen species (ROS)}

Among the 20 natural amino acids, the sulfur-containing Met and Cys, as well as the aromatic His, Trp, Tyr, and Phe contain the most oxidation-prone side chains (Davies and Truscott 2001). Oxidation may arise from photosensitization processes that can be distinguished in direct (type I) and indirect (type II) photo-oxidation, depending on whether the oxidation of the target occurs via direct absorption of light followed by electron transfer, or through interaction with singlet oxygen $\left({ }^{1} \mathrm{O}_{2}\right)$ (Scheme 1a). In the first mechanism, direct interaction of an endogenous chromophore (e.g., an aromatic moiety) with UV light results in the production of excited states, followed by electron transfer to suitable acceptors such as molecular oxygen $\left(\mathrm{O}_{2}\right)$ or disulfides (Benasson et al. 1983) to give the corresponding radical cations and reactive oxygen species (ROS), including the superoxide radical anion $\left(\mathrm{O}_{2}^{-}\right)$and its disproportionation products hydrogen
Scheme 1 Oxidation processes generating reactive oxygen species (ROS) by a photosensitization and $\mathbf{b}$ metal catalysis

\section{(a) Photosensitization}

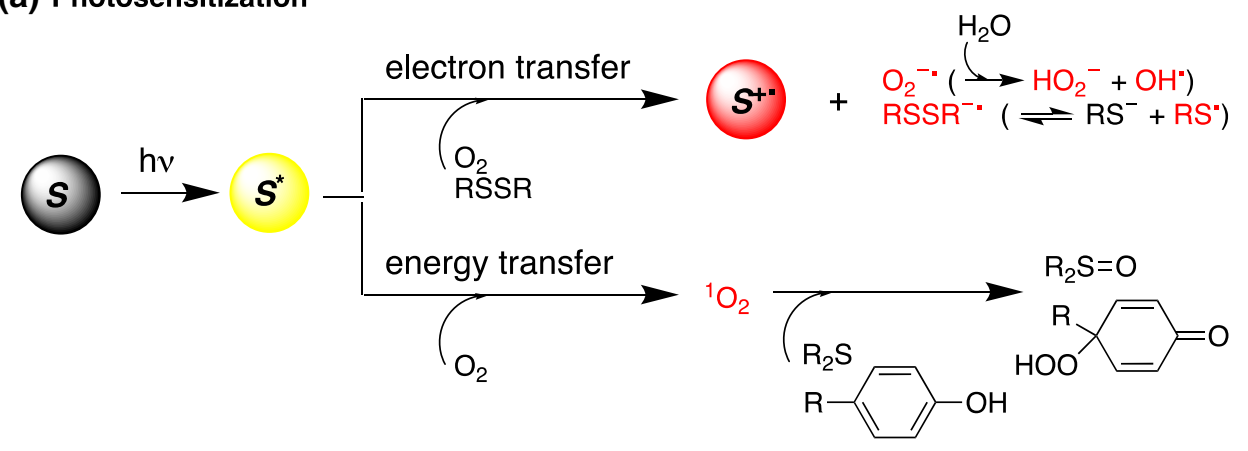

(b) Metal-catalyzed generation of ROS 
peroxide $\left(\mathrm{H}_{2} \mathrm{O}_{2}\right)$ and hydroxyl radical $\left(\mathrm{OH}^{*}\right)$ (Davies and Gilbert 1992), or disulfide radical anions in equilibrium with thiolates and thiyl radicals (Schöneich 2012, 2016).

The second mechanism, by which photo-oxidation may occur in proteins, involves indirect energy transfer to $\mathrm{O}_{2}$ from a photosensitizer, which generates ${ }^{1} \mathrm{O}_{2}$ in situ (Scheme 1a). This reacts with sulfides and aromatic residues of proteins, producing sulfoxides, hydroperoxides, and other derivatives (Davies and Truscott 2001; Ghogare and Greer 2016).

Besides photosensitization processes, transition metals, such as $\mathrm{Fe}(\mathrm{II})$ or $\mathrm{Cu}(\mathrm{I})$, have been also widely recognized as efficient catalysts for oxidative processes in proteins, which are referred to as metal-catalyzed oxidations (MCOs). The latter involve either direct metal-induced oxidation of the target, or, most commonly, the reaction of the target with ROS that are produced by transition-metal complexation of molecular oxygen in the presence of an appropriate electron donor (e.g., ascorbate) (Scheme 1b) (Li et al. 1995).

Oxidation processes may occur during production, purification, and storage, leading to the conversion of oxidation-prone residues to the corresponding oxidized species (Table 1), and, eventually, to substantial alteration of the protein stability and folding (Torosantucci et al. 2014).

\section{Mechanisms of methionine oxidation}

Oxidation of solvent-exposed Met residues in proteins has long being object of study, and significant efforts have been made to gain deeper insights into the mechanistic features of this reaction as well as the biological consequences resulting therefrom (Torosantucci et al. 2014). Formally, Met can undergo oxidation through a double- (by non-radical oxidants such as peroxides or hypochlorous acid) or singleelectron transfer (e.g., by metal catalysis or photo-irradiation) (Schöneich 2005). In the presence of $\mathrm{H}_{2} \mathrm{O}_{2}$, the doubleelectron oxidation occurs at the sulfur atom producing the corresponding diastereomeric sulfoxide products in equal amounts (Sharov et al. 1999), which may further oxidize to sulfones under strong oxidizing conditions (Garner et al. 1998; Schöneich 2005) (Scheme 2a). The reaction follows a $\mathrm{pH}$-independent mechanism involving a nucleophilic attack of the Met sulfide on the oxygen atom of the oxidant to form a water-stabilized intermediate, followed by proton transfer (Chu et al. 2004).

Met oxidation may also involve the hydroxyl radical $\mathrm{OH}^{\text {; }}$, which affords different products depending on $\mathrm{pH}$, substrate concentration, and/or neighboring groups. It has been shown that addition of $\mathrm{OH}^{\circ}$ occurs predominantly at the sulfur atom to yield a hydroxysulfuranyl radical (Bonifacic et al. 2000). The latter may be protonated at acidic $\mathrm{pH}$ and eliminate a water molecule, generating the corresponding sulfide radical cation that is stabilized by association with a non-oxidized Met residue in a sulfur-sulfur three-electron-bonded complex (Schöneich 2005; Yashiro et al. 2005) (Scheme 2b). An intramolecular sulfur-amide oxygen three-electron bonded complex can also be formed during the Fenton reaction of the Met-His sequence, which leads to hydrolysis of the Met-His peptide bond (Mozziconacci et al. 2013, 2016b). At neutral $\mathrm{pH}$, the hydroxysulfuranyl radical may undergo an intramolecular acid-base reaction with a protonated amino group, which leads to water elimination and a stabilized sulfur-nitrogen three-electron-bonded complex. However, this species is in equilibrium with sulfide or amino-radical cations that may decompose via heterolytic cleavage of neighboring bonds (Scheme 2c) (Schöneich et al. 1994).

Besides water elimination by protonation of the $\mathrm{OH}$ group, the hydroxysulfuranyl radical may eliminate water by hydrogen abstraction from neighboring alkyl groups, generating alkyl radicals that can be converted into peroxyl radicals by reaction with $\mathrm{O}_{2}$. These, in turn, can oxidize a second Met residue to sulfoxide (Schöneich et al. 1993) (Scheme 2d). Alkyl radicals of Met residues can be built also by the corresponding sulfide radical cation upon proton abstraction (Schöneich et al. 1993).

Generation of the Met sulfide radical cation can also be triggered by light (Scheme 2e). For example, in a type I photo-oxidation, electron transfer from the sulfur atom to a triplet sensitizer like benzophenone or 4-carboxybenzophenone occurs, leading to the sulfide radical cation that can additionally produce Met alkyl radicals by proton abstraction (Pedzinski et al. 2009). Type II oxidation has also been reported (Scheme 2f): in this case, the reaction with ${ }^{1} \mathrm{O}_{2}$ builds a zwitterion intermediate that may either oxidize a second Met residue with the production of two $\operatorname{Met}(\mathrm{O})$ at acidic $\mathrm{pH}$, or be converted into $\operatorname{Met}(\mathrm{O})$ with formation of
Table 1 Common oxidation products of oxidation-prone amino acids

\begin{tabular}{ll}
\hline Residue & Oxidation product \\
\hline Met & Sulfoxide, sulfone \\
Cys & Sulfinic and sulfonic acid, di- and trisulfide \\
His & 2-oxo-His, cross-linked adducts \\
Trp & Hydroxy-Trp, kynurenine (Kyn), 3-hydroxy-Kyn, N-formyl-kynurenine (NFK), 3-hydroxy-NFK \\
Tyr & 3,4-Dihydroxyphenylalanine (DOPA), 2-amino-3-(3,4-dioxocyclohexa-1,5-dien-1-yl) propanoic \\
& acid (DOCH) \\
\hline
\end{tabular}




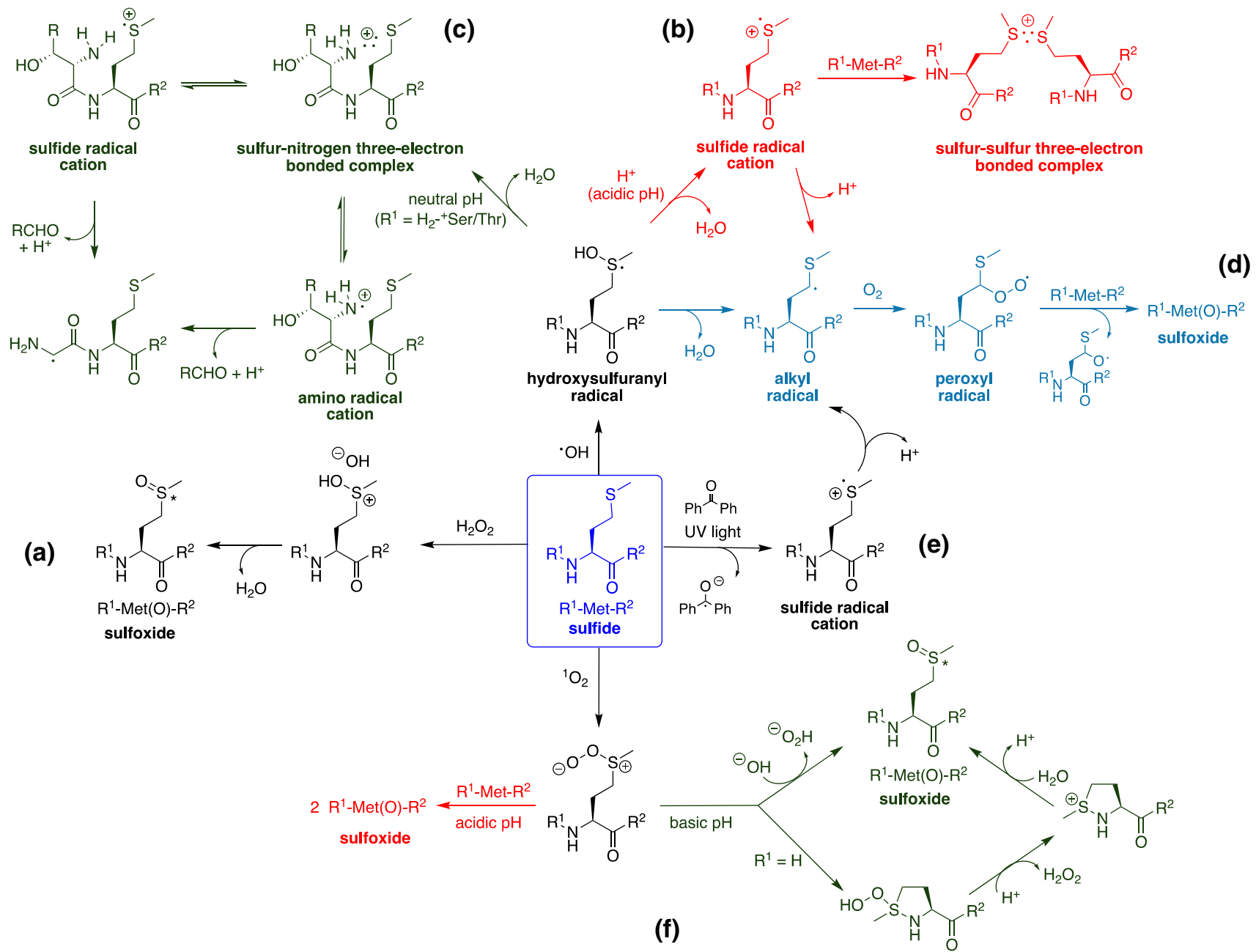

Scheme 2 Possible oxidation processes of Met. a Double-electron and b-d single-electron transfer as well as $\mathbf{e}, \mathbf{f}$ photo-oxidation mechanisms are shown

$\mathrm{H}_{2} \mathrm{O}_{2}$ at basic $\mathrm{pH}$ by an intramolecular or intermolecular mechanism (Sysak et al. 1977).

\section{Susceptibility of mAbs to methionine oxidation}

Met oxidation in protein therapeutics has been correlated with a number of adverse effects, including loss of function (Hsu et al. 1996), decrease in folding stability (Mulinacci et al. 2011), as well as increase in aggregation propensity (Mulinacci et al. 2013). Met oxidation in vitro is generally obtained by treatment with oxidizing agents such as $\mathrm{H}_{2} \mathrm{O}_{2}$ (Li et al. 1995; Regl et al. 2017), $t$-butylhydroperoxide ( $t$ BHP) (Li et al. 1995), or with UV light irradiation (Lam et al. 1997; Wei et al. 2007). However, the susceptibility of a Met residue to oxidation significantly depends on its location within the protein structure. For example, when subjecting the recombinant IgG1 antibody HER2 to a $20 \mathrm{~h}$ treatment with $t$ BHP, light-chain Met- 4 and heavy-chain Met-107 and Met-361 were only slightly oxidized, whereas the two solvent-exposed heavy-chain Met-255 and Met-431, both located in the Fc region, underwent significant oxidation (Shen et al. 1996). Interestingly, when a fully human recombinant IgG1 monoclonal antibody was incubated in formulation buffer for 12 months at $25{ }^{\circ} \mathrm{C}$, the preferential oxidation of Met-255 and Met-431 occurred only on one heavy chain, differently from a chemically stressed sample subjected to $t$ BHP treatment, which was oxidized at both heavy chains (Chumsae et al. 2007).

Due to the structural perturbation induced, oxidation of Met-255 and Met-431 has been associated with altered thermal stability as well as to aggregation and deamidation propensity of the Fc part (Liu et al. 2008). In addition, decreased binding affinity for protein $\mathrm{A}$, protein $\mathrm{G}$ and neonatal $\mathrm{Fc}$ receptor $\left(\mathrm{FcR}_{\mathrm{n}}\right)$ has been observed (Bertolotti-Ciarlet et al. 2009; Gaza-Bulseco et al. 2008; Pan et al. 2009), together with a reduction of the serum half-life for highly oxidized species (Wang et al. 2011b). Besides IgG1 Met-431 oxidation, also fragmentation between Met-431 and His-432 
upon MCO conditions was detected, which resulted in the formation of soluble and insoluble aggregates (Mozziconacci et al. 2016b).

\section{Mechanisms of cysteine oxidation}

Due to the nucleophilicity and the different oxidation states of the sulfur atom, Cys residues are the most oxidation-prone sites in proteins. Disulfides, which represent one of the most abundant oxidation products of Cys, may undergo type I photo-ionization, leading to the formation of radical ions (RSSR ${ }^{+}$and $\mathrm{RSSR}^{-}{ }^{-}$). Alternatively, they can also act as quenchers of excited states of Tyr and Trp residues. Radical disulfide anions ( $\mathrm{RSSR}^{-}{ }^{-}$) may either dissociate into thiolates and thiyl radicals $\left(\mathrm{RS}^{*}\right)$, or react with molecular oxygen to produce superoxide radical anions $\left(\mathrm{O}_{2}^{-}\right)$(Scheme 3a) (Davies and Truscott 2001; Millington and Church 1997; Wardman and Vonsonntag 1995).

The thiyl radicals $\left(\mathrm{RS}^{\circ}\right)$ can give rise to a series of reactions including hydrogen abstraction from $\mathrm{C}-\mathrm{H}$ bonds or reactions with $\mathrm{O}_{2}$ to generate an intermediate thiyl peroxyl radical (RSOO') that rearranges into a sulphonyl radical $\left(\mathrm{RS}(\mathrm{O}) \mathrm{O}^{*}\right)$ as precursor of sulfinic acid $(\mathrm{RS}(\mathrm{O})$ $\mathrm{OH})$ (Scheme 3b). Alternatively, the formation of sulfenic (RSOH) and sulfonic $\left(\mathrm{RS}(\mathrm{O})_{2} \mathrm{OH}\right)$ acids from $\mathrm{RSOO}^{\circ}$ has also been observed (Scheme 3c) (Becker et al. 1988; Millington and Church 1997; Schöneich 2012; Sevilla et al. 1988; Tamba et al. 1995; Wardman and Vonsonntag 1995).

The reaction of Cys with $\mathrm{H}_{2} \mathrm{O}_{2}$ in aqueous solution produces a sulfenic acid intermediate that, depending on the thiol density and $\mathrm{pH}$ of the microenvironment surrounding the Cys residue, may either form disulfide bonds or further oxidize to sulfinic and sulfonic acids, or undergo cyclization to sulfenamide (Scheme 3d).

\section{Noncanonical disulfide and trisulfide bridges in $\mathbf{m A b s}$}

Thiol-disulfide exchange reactions, which favor the formation of native from non-native disulfide bonds, occur during the oxidative folding of proteins and are usually mediated by specialized enzymes like protein disulfide isomerase (PDI) (Hudson et al. 2015; Moroder and Buchner 2008). In contrast, the accumulation of non-native disulfide bonds favors protein misfolding and aggregation (Hawe et al. 2009; Jordan et al. 1994). Occurrence of noncanonical disulfide bonds has been observed in mAbs and has been correlated with the existence of half molecules (Bloom et al. 1997; Schuurman et al. 2001), hybrids (Schuurman et al. 1999; Yoo et al. 2003), as well as structural isoforms presenting different hydrodynamic size, higher order structures, and potency (Dillon et al. 2008; Martinez et al. 2008).

Besides noncanonical disulfide bonds, also trisulfides have been detected in all subclasses of recombinant IgGs, which were mostly formed between light and heavy chains or two heavy chains to an extent directly dependent on the fermentation parameters employed (Gu et al. 2010). A nonenzymatic mechanism based on a thiol-disulfide exchange has been proposed (Nielsen et al. 2011), in which the reaction of a disulfide with a sulfhydryl anion $\left(\mathrm{HS}^{-}\right)$generates a perthiolate and a thiol; the perthiolate can reduce another disulfide-containing molecule to form a mixed trisulfide that can further undergo reshuffling to a new trisulfide or a disulfide (Scheme 4).

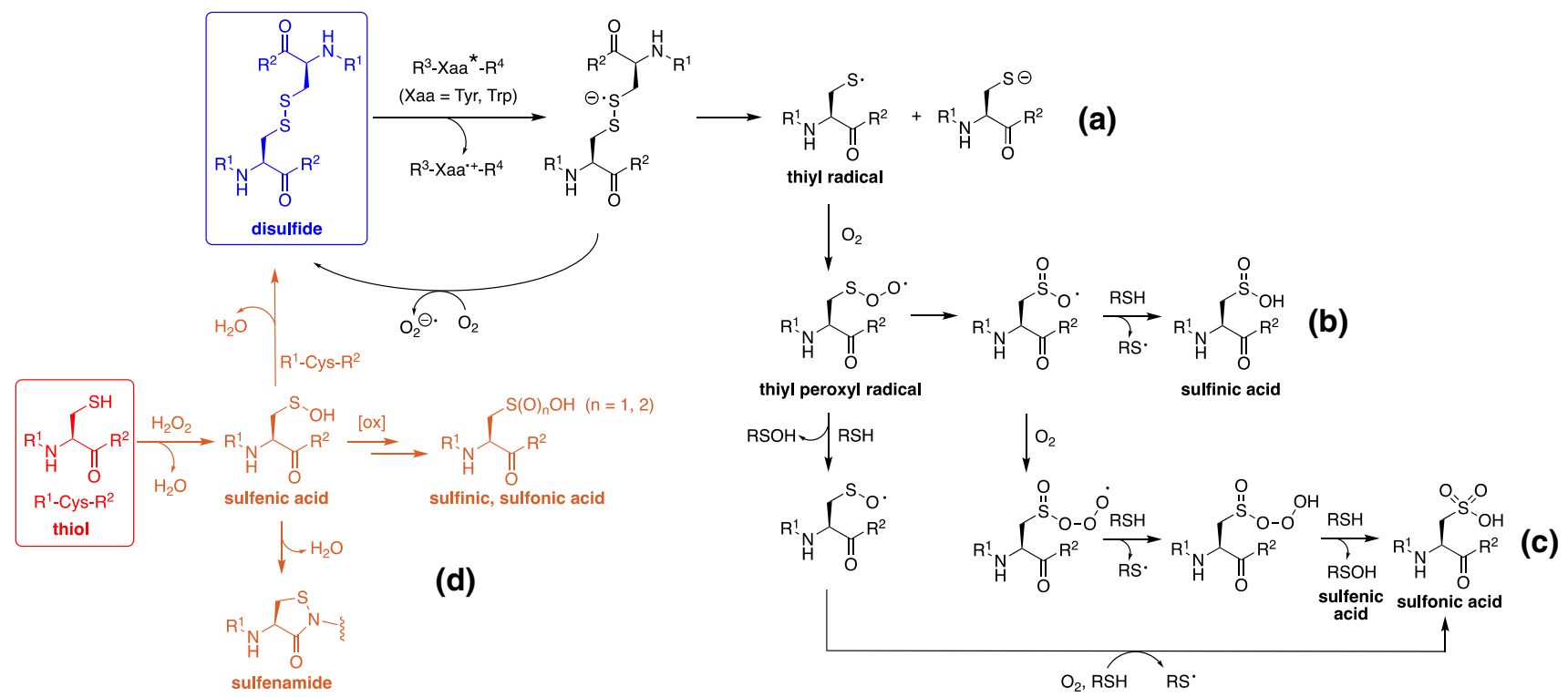

Scheme 3 Possible oxidation processes of a-c cystine and $\mathbf{d}$ cysteine 


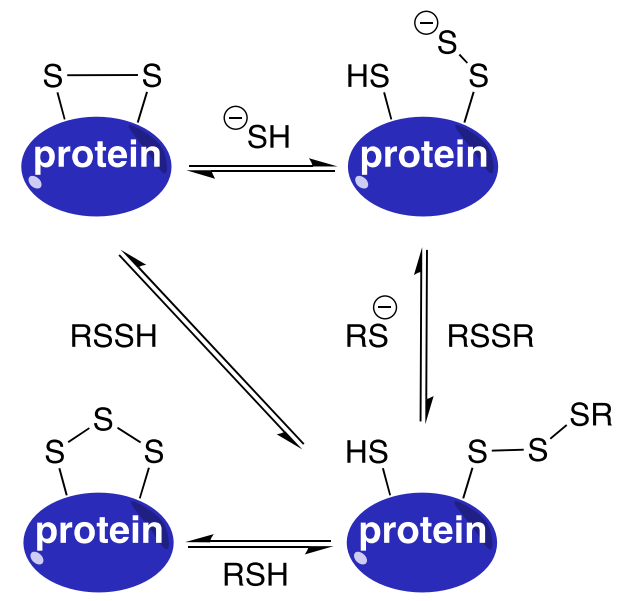

Scheme 4 Possible thiol-disulfide exchanges leading to trisulfide bonds

\section{Mechanisms of histidine oxidation}

Oxidation of His occurs mainly via type II photo-oxidation or MCO mechanisms (Davies and Truscott 2001; Schöneich 2000). In the first case, the reaction follows a [2+4] cycloaddition mechanism, in which the imidazole ring of His reacts with ${ }^{1} \mathrm{O}_{2}$ and forms 2,4- or 2,5-endoperoxide intermediates, depending on the $\mathrm{pH}$ and, consequently, on the protonation state of the imidazole ring (Huvaere and Skibsted 2009; Liu et al. 2014a). At basic pH, the reaction pathway involves the formation of a 2,4-endoperoxide intermediate, which rapidly converts into 4-hydroxy-2oxo-His (Scheme 5a). The latter presents an electrophilic site at C-5 that may undergo nucleophilic attack either by the $\alpha$-amine to form the corresponding intra-residue bicyclic product, or by another nucleophile from the surrounding environment, giving rise to cross-linked products (Amano et al. 2014; Lei et al. 2017; Xu et al. 2017). Instead, water addition at C-5 (directly or via epoxide formation) leads to 4,5-dihydroxy-2-oxo-His that may further decompose to aspartic acid, asparagine and urea via the 4-hydroxy-2,5-dioxo-His intermediate (Scheme 5a) (Agon et al. 2006; Tomita et al. 1968).

Different products are obtained at neutral $\mathrm{pH}$, where the 2,5-endoperoxide precursor converts into the corresponding 2-hydroxy-5-oxo-His and 5-hydroxy-2-oxo-His, which do not undergo any cyclization or other nucleophilic attack due to steric hindrance at the C-4 position (Scheme 5a).

In the case of MCO of His, the hydroxyl radical may react quite randomly and attack the imidazole ring of His at C-2, C-4 or C-5 positions to build 1,3-dihydro-2-oxoHis, and, in case of C-4 or C-5 addition, also other degradation products (Schöneich 2000) (Scheme 5b).

\section{Susceptibility of biotherapeutics to histidine oxidation}

His photo-oxidation was observed in an IgG1 mAb as a result of light exposure or of treatment with $\mathrm{H}_{2} \mathrm{O}_{2}$ in the presence of molybdate for ${ }^{1} \mathrm{O}_{2}$ generation, and it was shown to occur preferentially at His-289 due to the high solvent accessibility and, also, to the catalytic effect exerted by the surrounding amino acids (Amano et al. 2014). In another study, photocross-linking of the two IgG1 heavy chains via His-228 in the hinge region was detected, suggesting alternative processes for His oxidation to 4-hydroxy-2-oxo-His that then undergoes cross-linking (Liu et al. 2014b). Similarly, in high-molecular-weight (HMW) fractions of a 1-year-old IgG1 sample that was not light-stressed, His-228, His-289, and His-437 were identified as hot-spots for cross-linking reaction with Lys or Cys (Xu et al. 2017).

For a monoclonal $\operatorname{IgG} 2,1,3$-dihydro-2-oxo-His was the preferential MCO product of His-304 and His-428 upon treatment with $\mathrm{Cu}^{2+}$ /ascorbate, which was attributed to a putative copper-binding site between these His residues and the neighboring Met-246 (Luo et al. 2011). In the case of the human growth hormone, treatment with $\mathrm{Cu}^{2+} /$ ascorbate resulted in extensive oxidation of His-18 and His-21, which are both located in the metal-binding site. While His- 21 provided also oxidation products other than 1,3-dihydro-2-oxoHis, thus suggesting a C-4 and/or C-5 addition, His- 18 was quantitatively oxidized to 1,3-dihydro-2-oxo-His, which is indicative of a direct C-2 addition and/or of initial addition on C-4 and/or C-5 followed by a hydroxyl radical shift mediated by efficient water elimination/addition (Schöneich 2000; Zhao et al. 1997) (Scheme 5b). MCO products of His were also observed in insulin samples, where the reaction selectively occurred across the B chain with formation of 1,3-dihydro-2-oxo-His at both residues involved in zinc ion binding (Hovorka et al. 2002; Sadineni and Schöneich 2007).

\section{Mechanisms of tryptophan oxidation}

With its indole group, Trp represents the strongest chromophore in proteins, and its photo-oxidation gives rise to a complex mixture of products (Davies 2003, 2004; Ehrenshaft et al. 2015; Langlots et al. 1986; Pattison et al. 2012; Saito et al. 1977). Type II photo-oxidation of Trp follows a $[2+2]$ cycloaddition mechanism involving a C-2, C-3-dioxiethane intermediate that converts into $N$-formylkynurenine (NFK), kynurenine (Kyn) by deformylation of NFK, or a diastereomeric mixture of oxindolylalanine (Oia) and dioxindolylalanine (diOia) (Zhang et al. 1993). Alternatively, ${ }^{1} \mathrm{O}_{2}$ may add to the indole group through an enereaction giving tryptophanyl-hydroperoxide, followed by a nucleophilic attack of the hydroperoxide or of the $\alpha$-amino group at the imine, which leads, respectively, to 
(a)

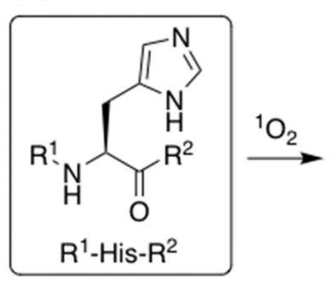<smiles></smiles>

or<smiles>[R1]NC(CC1=NC2OOC1C2=O)C([R])=O</smiles>

2,4- or 2,5-endoperoxide<smiles>[R1]NC(CC1=NC(=O)N=C1)C([R])=O</smiles>

(2-0xo)-His

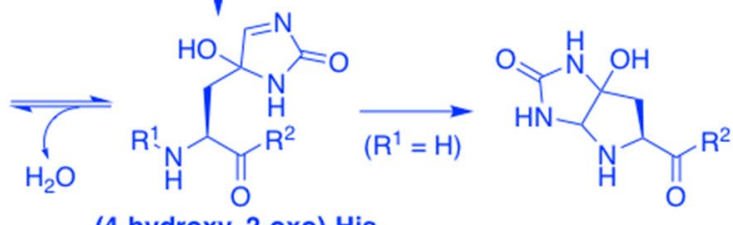

(4-hydroxy, 2-oxo)-His

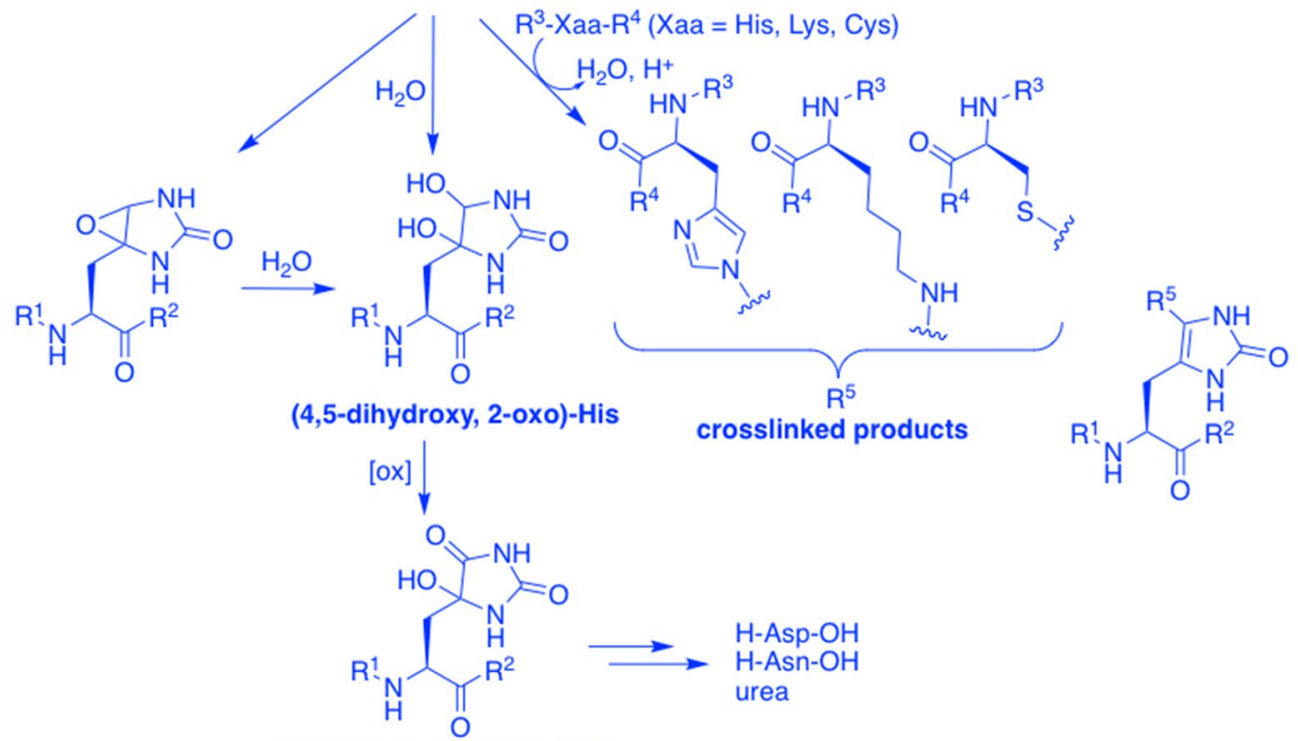

(4-hydroxy, 2,5-dioxo)-His

(b)

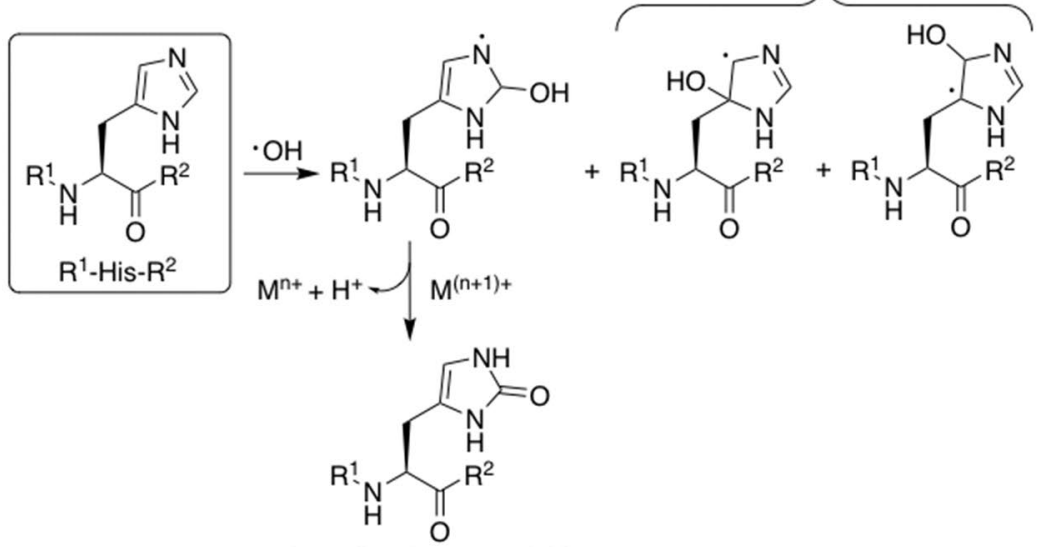

(1,3-dihydro, 2-oxo)-His

Scheme 5 Possible oxidation processes of His by a photo-oxidation and $\mathbf{b}$ MCO 
the dioxiethane intermediate or to a pyrroloindole derivative (Scheme 6a) (Gracanin et al. 2009; Nakagawa et al. 1977).

Furthermore, type I photo-oxidation of Trp results in a radical cation $\left(\operatorname{Trp}^{+}\right)$that undergoes either $\mathrm{C} \alpha-\mathrm{C} \beta$ homolytic cleavage (Schöneich 2018) or deprotonation of the NH group of the indole ring to generate a tryptophanyl (indolyl) radical (Trp') (Creed 1984a). This species may capture a superoxide radical anion $\left(\mathrm{O}_{2}^{-}\right)$to form tryptophanyl-hydroperoxide that may undergo intramolecular cyclization to generate a C-2, C-3-dioxetane intermediate or a pyrroloindole derivative (Aspee and Lissi 2000). Alternatively, also dimers and trimers arising from the tryptophanyl radical $\left(\operatorname{Trp}{ }^{*}\right)$ have been detected upon photo-oxidation in the presence of riboflavin (Silva et al. 2019) (Scheme 6b).

MCO mechanisms have been reported, as well, which lead to oxidized Trp species including hydroxy-Trp, NFK, and Kyn (Finley et al. 1998).

\section{Susceptibility of mAbs to tryptophan oxidation}

Oxidative modification of Trp has been shown to depend both on the identity of the neighboring amino acids and on its location in the protein structure (Pigault and Gerard 1984; Tassin and Borkman 1980), and ad-hoc developed RP-HPLC-based methods have been employed for its determination and characterization in biopharmaceuticals (Yang et al. 2007). Irradiation of a mAb with near UV-visible light resulted in extensive oxidation of Trp-50 and Trp-104 in the heavy chain, and of Trp-90 in the light chain, with Trp104 exhibiting the fastest oxidation rate, with concomitant formation of Kyn, NFK, 5-OH-Trp, Oia, and diOia (Li et al. 2014). Similarly, exposure of the humanized mAb MEDI493 to UV light caused substantial oxidation of heavychain Trp-105, which was accompanied by a substantial decrease in binding affinity for the corresponding antigen (respiratory syncytial virus F protein), with a significant decrease in potency (Wei et al. 2007). Also in the case of

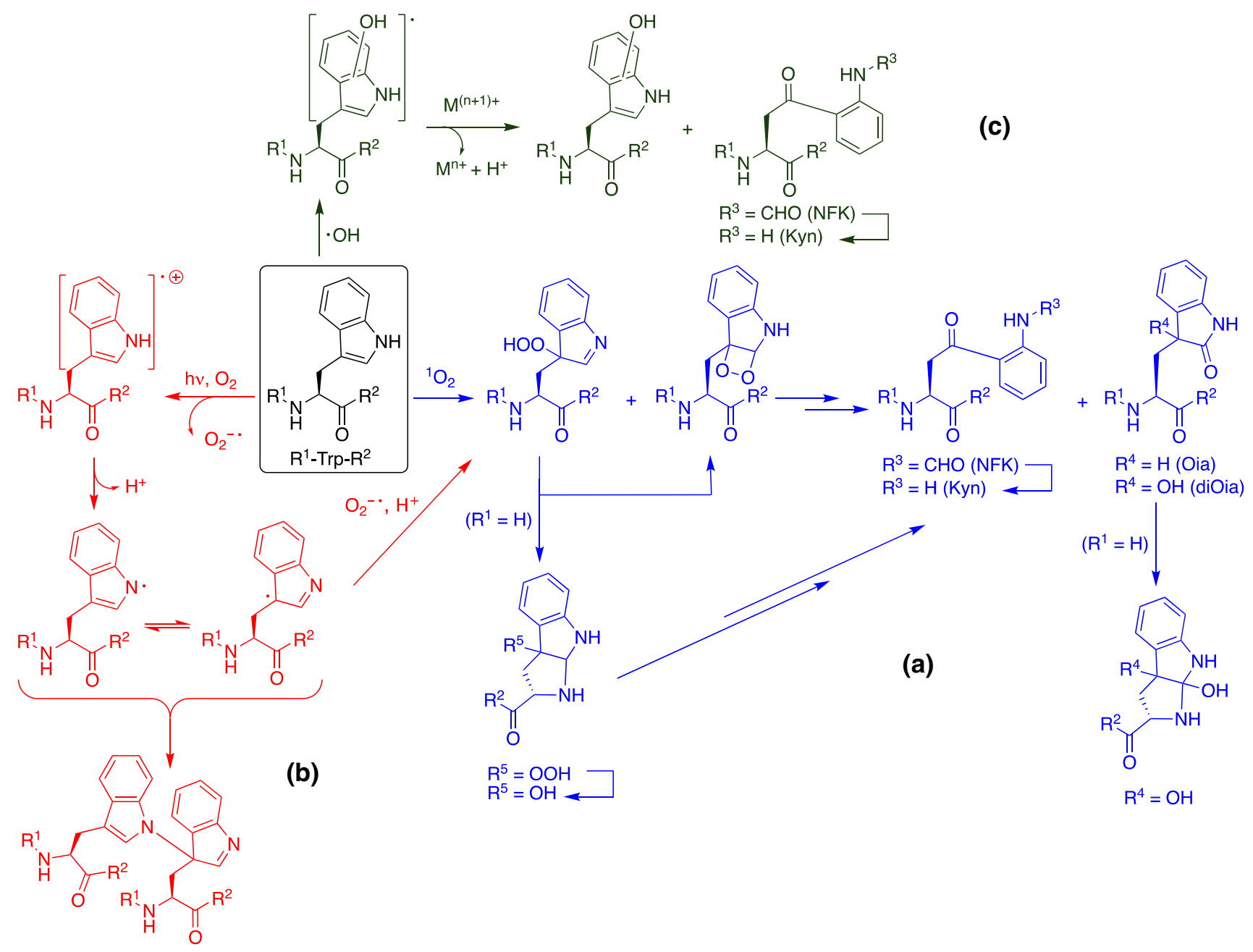

Scheme 6 Possible oxidation processes of Trp by $\mathbf{a}, \mathbf{b}$ photo-oxidation and $\mathbf{c}$ MCO 
the recombinant IgG1 antibody HER2, progressive oxidation of the solvent-exposed Trp-32 induced by treatment with $t \mathrm{BHP}$ was accompanied by a decrease in the binding affinity to the own target. Interestingly, the complementary determining region (CDR), where Trp-32 is located, was found to be more susceptible to the oxidation conditions used than the heavy-chain Met-429 and Met-107 (Hensel et al. 2011).

\section{Mechanisms of tyrosine oxidation}

Analogously to Trp, photo-oxidation of Tyr is one of the major oxidative degradation processes in peptides and proteins. ${ }^{1} \mathrm{O}_{2}$ mediated oxidation was reported to proceed under basic conditions with the formation of unstable endoperoxides that rearrange into hydroperoxides. The latter contain a Michael acceptor system that can react with various nucleophiles leading to intra-residue cyclization or inter-residue cross-linking (Scheme 7a) (Rizzuto and Spikes 1977; Wright et al. 2002).

Oxidation of Tyr side chains may also be mediated by radical species, resulting either from MCO (Ali et al. 2004) or type I photo-oxidative events (Creed 1984b). In the latter case, the reaction mechanism proceeds analogously to that observed for Trp, with the formation of a Tyr radical cation. This may undergo the homolytic cleavage of the $\mathrm{C} \alpha-\mathrm{C} \beta$ bond, resulting in a protonated quinone methide and a C $\alpha$-glycyl radical (Kang et al. 2019), or it may build a phenoxyl radical through proton loss (Scheme $7 \mathrm{~b}$ ). The phenoxyl radical may either dimerize to give $\mathrm{C}-\mathrm{O}$ or $\mathrm{C}-\mathrm{C}$ dityrosine adducts (Aeschbach et al. 1976; Garrison 1987), or further oxidize to form $p$ - or $o$-hydroperoxide intermediates that may react with vicinal nucleophilic residues (Garrison 1987; Ito et al. 1988; Moller et al. 2012; Winterbourn et al. 2004). Alternatively, the $o$-hydroperoxide may form an $o$-benzoquinone (DOCH) that is susceptible to Michael additions (Ito et al. 1984), or it may further convert into dihydroxy phenylalanine (DOPA) (Bielski et al. 1985; d'Alessandro et al. 2000; Song and Buettner 2010).

\section{Susceptibility of biotherapeutics to tyrosine oxidation}

Tyr oxidation has been detected in protein therapeutics after oxidative treatments. For example, in interferon $\beta$, oxidative modification of Tyr was induced with $\mathrm{Cu}^{2+} /$ ascorbate and resulted in the formation of highly immunogenic aggregates

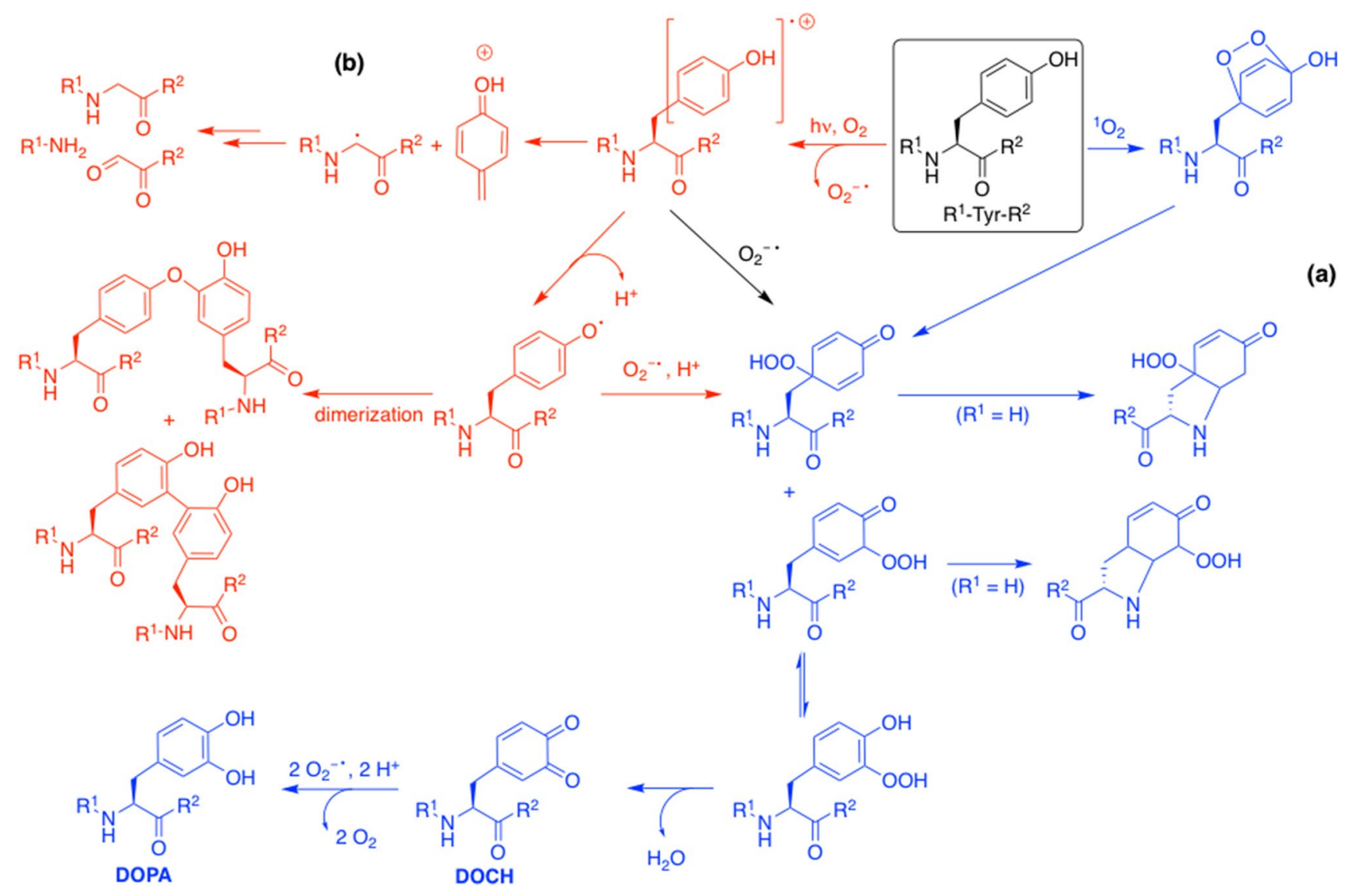

Scheme 7 Possible type II (a) and I (b) photo-oxidation processes of Tyr 
arising from 1,4- or 1,6-type addition of the $\mathrm{N}$-terminus or Lys-105 side chain to the $o$-benzoquinone degradation product of Tyr-20, Tyr-60, Try-126, or Phe-11 (Torosantucci et al. 2013).

Oxidation of insulin with $\mathrm{Cu}^{2+} /$ ascorbate resulted in the formation of the $o$-benzoquinone DOCH and DOPA at Tyr positions B16, B26, A14, and A19, with subsequent formation of cross-linked aggregates (Torosantucci et al. 2012). In another example, MCO of insulin with $\mathrm{H}_{2} \mathrm{O}_{2} / \mathrm{Cu}$ formed dityrosine, which resulted in a significant decrease in glucose oxidation capability (Olivares-Corichi et al. 2005), similarly to what observed by comparing the decrease in biological activity of insulin following either Fenton oxidation or incubation in diabetic patient's plasma (MontesCortes et al. 2010). UV light treatment of the Fc region of $\mathrm{IgG} 4$ was shown to produce degradation products of Tyr at positions 300,373 , and 436 , corresponding to glycine and glyoxal amide (Kang et al. 2019).

\section{Mechanisms of phenylalanine oxidation}

Oxidation of Phe follows predominantly photo-oxidative mechanisms (Scheme 8) (Bent and Hayon 1975). Absorption of UV light may induce photodissociation generating the benzyl radical, or photo-ionization yielding, like in the case of Trp and Tyr, a radical cation and its hydroxylated ring products that, then, undergo degradation pathways in analogy to those observed for Tyr (Davies and Gilbert 1992).

MCO of Phe has also been observed (Ashraf et al. 1980): in this case, direct reaction with the hydroxyl radical was suggested to occur at the $\mathrm{C} \alpha$ position with formation of an $\alpha$-keto acid that degrades to aldehyde products and $\mathrm{CO}_{2}$.

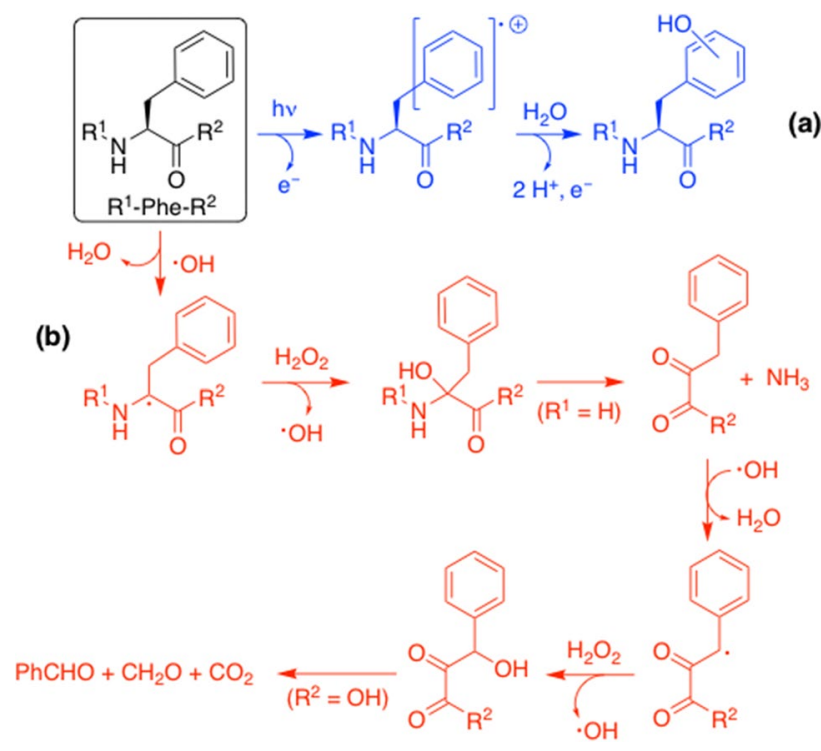

Scheme 8 Possible type I (a) and MCO (b) processes of Phe

\section{Intra- and inter-residue cyclizations upon loss of water or ammonia}

\section{Mechanisms of asparagine and aspartic acid degradation}

Both Asp and Asn residues are subjected to spontaneous degradation reactions that may lead to a variety of side products, depending on the environmental conditions and the local conformation (Clarke 1987; Geiger and Clarke 1987; Patel and Borchardt 1990b). Under highly acidic conditions $(\mathrm{pH}<4)$, Asn residues may be converted into Asp residues by acid-catalyzed deamidation (Oliyai and Borchardt 1993; Patel and Borchardt 1990a), which further promotes the acid-catalyzed formation of succinic anhydride upon cleavage of the peptide bond following Asp, especially when the $n+1$ position is occupied by Pro (Marcus 1985) (Scheme 9a). Peptide-bond cleavage may occur under acid conditions also before Asp, when Gly is present at the n-1 position, probably by formation of a six-membered cyclic intermediate (Marcus 1985; Patel and Borchardt 1990b) (Scheme 9a).

C-terminal Asn residues may be deamidated under acidic conditions also by a mechanism involving the formation of a succinic anhydride intermediate via intramolecular nucleophilic catalysis (Scheme 9b) (Darrington and Anderson 1994).

Under mildly acidic conditions ( $\mathrm{pH} 4-5$ ), Asn residues are mainly stable, whereas Asp residues are prone to form the succinimide (Snn) intermediate (Oliyai and Borchardt 1993; Patel and Borchardt 1990a). At $\mathrm{pH}>6$, the formation of the Snn intermediate becomes significant also for Asn (Patel and Borchardt 1990b). According to a generally recognized mechanism, the reaction proceeds through a nucleophilic attack of the peptide bond on the $\beta$-carbonyl side chain of Asn or Asp to form a metastable tetrahedral intermediate, from which ammonia or water is eliminated (Aylin et al. 2003; Capasso et al. 1989, 1991b, 1993; Oliyai and Borchardt 1993; Patel and Borchardt 1990a) (Scheme 9c). Interestingly, deamidation of Asn residues via the Snn intermediate is kinetically favored around pH 6 or higher (Patel and Borchardt 1990b), whereas it becomes less favored for Asp, which reflects the negative effect of the increased ionization of the aspartyl side chain (Capasso et al. 1992; Oliyai and Borchardt 1993; Patel and Borchardt 1990a). Once formed, the Snn intermediate undergoes water attack on either side of the imide nitrogen, $\mathrm{C} \alpha$ or $\mathrm{C} \beta$, followed by breakage of the corresponding $\mathrm{C}-\mathrm{N}$ bond to lead to a mixture of Asp and iso-Asp, the latter being produced in a two-to-fourfold excess (Xie et al. 1996). Furthermore, due to favorable inductive factors and resonance stabilization effects of the adjacent nitrogen 
(a)

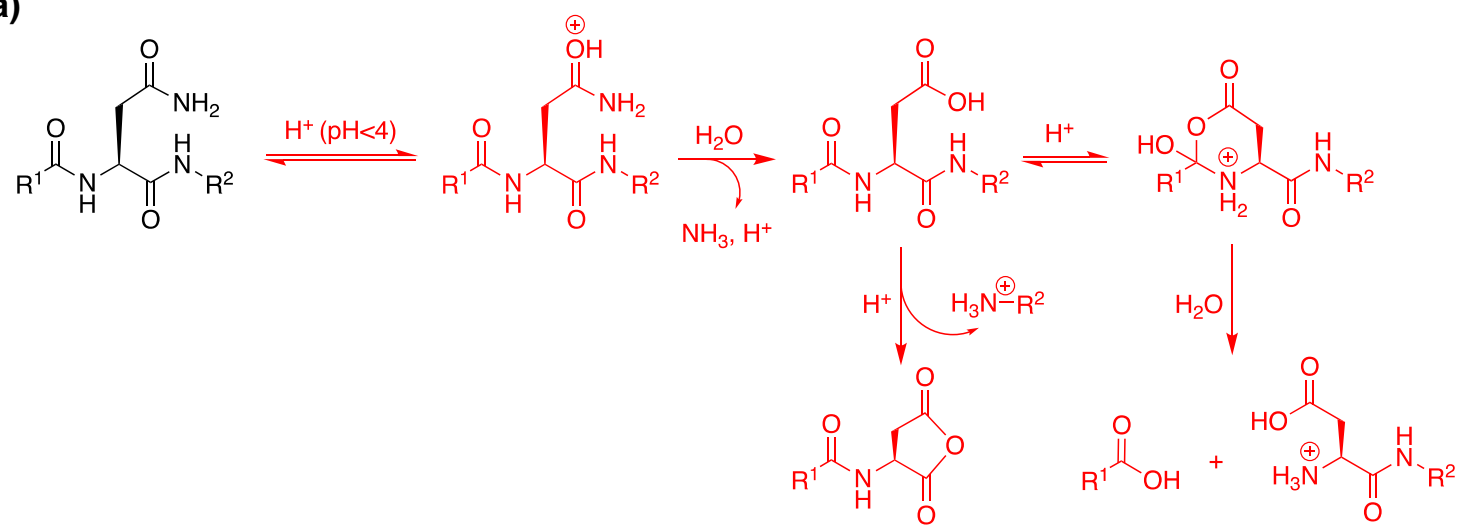

(b)<smiles>[R]C(=O)N[C@@H](CC(N)=O)C(=O)O</smiles>

(c)

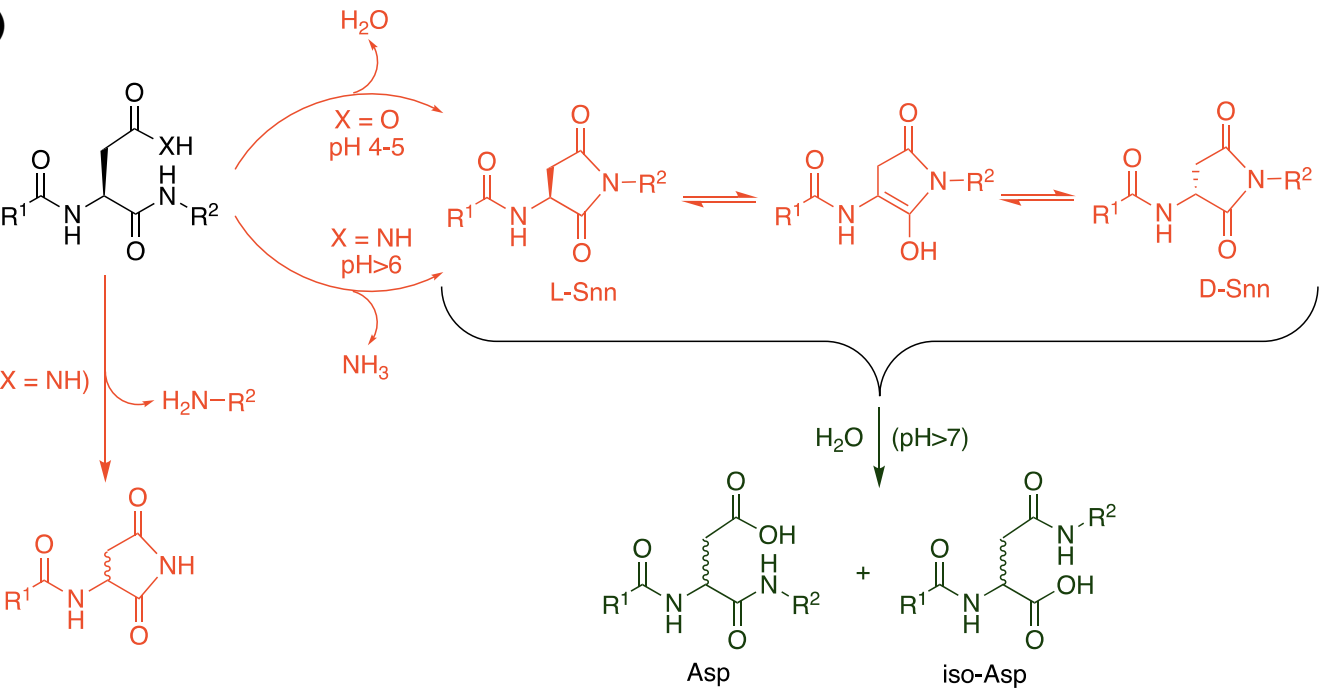

Scheme 9 Mechanisms of deamidation a-c of Asn and dehydration $\mathbf{c}$ of Asp

and $\beta$-carbonyl carbon, respectively, the Snn structure has inherent tendency to undergo base-induced racemization at $\mathrm{C} \alpha$ carbon (Radkiewicz et al. 1996).

Interestingly, Snn or succinic anhydride formation by intra-residue cyclization of Asn or Asp followed by peptide-bond cleavage was also observed, especially when the competitive mechanism leading to Asp and iso-Asp formation was slowed down by the presence of bulky residues at the $n+1$ position, such as Thr, Val, Leu, or Pro (Geiger and Clarke 1987; Patel and Borchardt 1990b; Tyler-Cross and Schirch 1991), as well as of His that, besides the steric hindrance, also acts as general base catalyst at neutral or basic pH (Goolcharran et al. 2000) (Scheme 9c).
Beside the $\mathrm{pH}$, other variables related to both external conditions and intrinsic properties of the chemical environment surrounding the Snn-prone site may affect the course of the reaction and the product profile. To this regard, the steric effect and electron-withdrawing properties of the amino acid adjacent to the sensitive site play a major role. Accordingly, amino acids with poor steric hindrance, above all Gly, at the $n+1$ position, give the highest extent of Snn formation, whereas more sterically hindered residues like Leu, Pro, Ile, Phe, and Val offer higher degree of protection (Behrendt et al. 2016; Patel and Borchardt 1990b; Robinson et al. 1973). Residues presenting a cationic side chain at physiological pH such as Lys and Arg may promote Snn formation 
by stabilization of the anionic tetrahedral intermediate and/ or by general acid catalysis. In the case of His, both general acid and base catalysis can be observed, depending on the pH (Goolcharran et al. 2000). Other neighboring groups, including the $\beta$-hydroxyl groups of Ser or Thr at the $n+1$ position (Patel and Borchardt 1990b; Robinson et al. 1973), have showed catalytic effects in the formation of Snn.

\section{Susceptibility of mAbs to asparagine and aspartic acid degradation}

Asn and/or Asp degradation products have been observed in proteins, including $\mathrm{mAbs}$, where they have been found both in Fab and $\mathrm{Fc}$ domains, and their impact on $\mathrm{mAb}$ stability, potency, and/or safety has been considered as the object of study (Reissner and Aswad 2003; Wang 1999). In such complex systems, structural factors as well as the extent of solvent exposure may greatly affect the degradation of Asn and Asp residues (Wakankar et al. 2007). For example, the CDR region of mAbs contains several Asp and Asn residues that may be considered hot-spot degradation points, depending on their location within the protein (Huang et al. 2005; Vlasak et al. 2009). In particular, Asn-30, Asn-55, and Asp-102 were shown to be particularly susceptible to isoAsp conversion, with consequent decrease in target binding affinity and potency of an antibody against HER/neu (Harris et al. 2001).

Deamidation has also been detected in the Fc region, particularly in the sequence motif Leu-Asn-Gly-Lys in the CH2 domain (Chelius et al. 2005; Mukherjee et al. 2010) and at Asn-384 and Asn-389 in the CH3 domain. Interestingly, the latter two residues converted mainly into iso-Asp and Asp, respectively, which was attributed to a specific effect of the local structure on the Snn hydrolysis pathway (Sinha et al. 2009). Within the $\mathrm{CH} 3$ domain, deamidation events were also reported along the C-terminal part, particularly at Asn-434 (Khawli et al. 2010), which is of biological relevance, as it has been shown that this residue is included in the binding site of human IgG1 to the FcRn (Shields et al. 2001; Ying et al. 2014). Therefore, alterations of Asn-434 may eventually alter the antibody presence in the circulation. However, it should be also mentioned that charge variants of a recombinant humanized IgG1 mAb did not show significantly different pharmacokinetic properties in serum (Khawli et al. 2010).

\section{Mechanisms of diketopiperazine formation}

Diketopiperazine (DKP) formation has been found in tryptic digests (Jornvall 1974), and also as degradation product of peptide solutions or formulations upon long storage (Oyler et al. 1991; Sepetov et al. 1991; Straub et al. 1995). The intramolecular cyclization proceeds by initial trans $\rightarrow$ cis isomerization of the peptide bond between the first two residues, followed by nucleophilic attack of the $\alpha$-amine of the first residue on the $\alpha$-carbonyl of the second residue to produce a zwitterionic intermediate that evolves into the DKP upon elimination of the third residue (Capasso et al. 1998) (Scheme 10). Interestingly, the zwitterionic intermediate has been proposed to rearrange at high temperatures $\left(100{ }^{\circ} \mathrm{C}\right.$ or higher) and $\mathrm{pH}>6$ to possible bicyclic intermediates that convert into the inverted linear dipeptidyl moiety or to the linear dipeptidyl moiety with epimerization of the first residue (Sepetov et al. 1991; Steinberg and Bada 1981, 1983) (Scheme 10a).

DKP formation can be both general base- and general acid-catalyzed (Capasso et al. 1998; Goolcharran and Borchardt 1998; Suzuki et al. 1981), although at basic $\mathrm{pH}$ values the trans $\rightarrow$ cis isomerization of the peptide bond becomes the rate-limiting step (Capasso et al. 1998). Moreover, the cyclization is favored by the presence of Pro or Gly at the second position (Gisin and Merrifield 1972).

Interestingly, DKP formation has also been observed in peptides containing amino-acid residues prone to Snn formation at position 2, as a result of the intramolecular attack of the free N-terminal amine on the $\alpha$-carbonyl of the Snn ring (Scheme 10b) (Brückner et al. 2012; Dehart and Anderson 2007; Jornvall 1974; Schon and Kisfaludy 1979).

\section{Mechanisms of glutamine and glutamic acid degradation}

As already reported for Asn residues, also Gln residues undergo direct deamidation under acidic conditions in a sequence-independent manner (Joshi et al. 2005; Robinson and Rudd 1974) (Scheme 11a). At pH close to 6, Gln side chains exhibit the highest stability (Scotchler and Robinson 1974). At neutral and basic pH, Gln deamidation proceeds via formation of a six-membered glutarimide intermediate (Scotchler and Robinson 1974; Robinson and Rudd 1974; Robinson et al. 1973). Water attack on one of the two carbonyl groups affords the corresponding $\gamma$-Glupeptide or $\alpha$-Glu-peptide, with a preference for the $\gamma$-residue (Scheme 11b) (Capasso et al. 1991a).

However, the formation of glutarimide is much less favored than the formation of Snn due to the higher distance of the $\gamma$-carbonyl group from the backbone (Robinson and Rudd 1974; Robinson et al. 2004), in accordance with the fact that Gln deamidation has been mainly detected in longlived proteins like $\beta \mathrm{B} 2$-crystallin in the human lens, which causes dimer destabilization (Lampi et al. 2006).

Contrarily to the deamidation of internal Gln residues, the deamidation of $\mathrm{N}$-terminal Gln residues may easily occur via intra-residue cyclization, which results in the formation of pyroglutamate (pGlu). Also N-terminal Glu residues may convert to pGlu, especially at $\mathrm{pH}$ around 4 
(a)

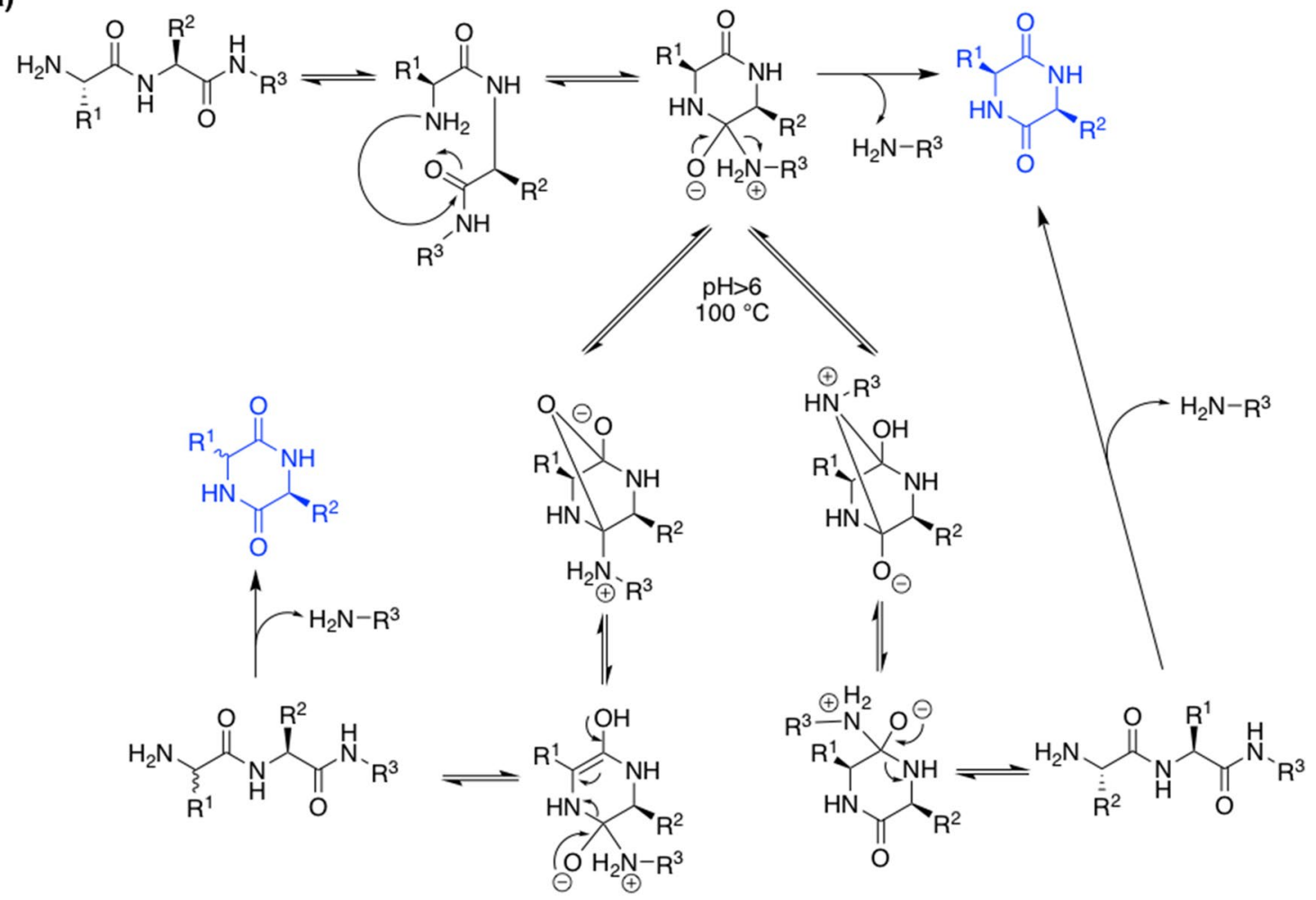

(b)<smiles>[R7]NC(=O)C[C@H]1NC(=O)[C@@H]([Z17])NC1=O</smiles>

Scheme 10 Mechanisms of DKP formation $\mathbf{a}$ at positions 1 and 2 of a peptide chain, and $\mathbf{b}$ in the presence of Snn at position 2

or 8, whereas the conversion slows down around $\mathrm{pH} 6-7$, suggesting weak-acid/base catalysis (Chelius et al. 2006; Dimarchi et al. 1982; Yu et al. 2006) (Scheme 11c).

Due to the more favored formation of the five-membered pyrrolidone than that of the six-membered glutarimide, degradation of Gln and Glu residues is mainly restricted to N-terminal Gln/Glu (Kumar and Bachhawat 2012; Perez-Garmendia and Gevorkian 2013). However, it should be taken into account that pGlu formation is not only a spontaneous reaction, but it can also be catalyzed by glutaminyl cyclase, an enzyme that is present in plants and mammalians (Fischer and Spiess 1987; Schilling et al. 2004). Indeed, in the case of the amyloid $\beta$ (A $\beta$ ) peptide, it was shown that inhibition of glutaminyl cyclase in vivo decreased the amount of the pGlu-containing A $\beta$ (Schilling et al. 2008), which is characterized by lower solubility (Schlenzig et al. 2009), higher proteolytic resistance (Rink et al. 2010) and more toxicity (Russo et al. 2002).

\section{Susceptibility of mAbs to pGlu formation}

The presence of pGlu is frequently detected in recombinant $\mathrm{mAbs}$, which is mainly attributed to spontaneous cyclization during both production (fermentation and purification) and storage (Chelius et al. 2006; Dick et al. 2006; Yu et al. 2006), and it is a reason for charge heterogeneity (Lyubarskaya et al. 2006; Moorhouse et al. 1997; Rehder et al. 2006). Nevertheless, no significant differences in comparison to the Gln/ Glu forms have been reported with regard to potency in vitro (Lyubarskaya et al. 2006), or clearance in humans (Liu et al. 2011).

\section{$\beta$-Elimination reactions of $\beta$-hydroxyl- and $\beta$-sulfhydryl-amino acids}

Ser, Thr, Cys, and cystine may undergo an acid- or basecatalyzed $\beta$-elimination reaction that results in dehydroalanine ( $\Delta$ Ala), $\beta$-methyl- $\Delta \mathrm{Ala}$, and, in case of cystine, 
(a)

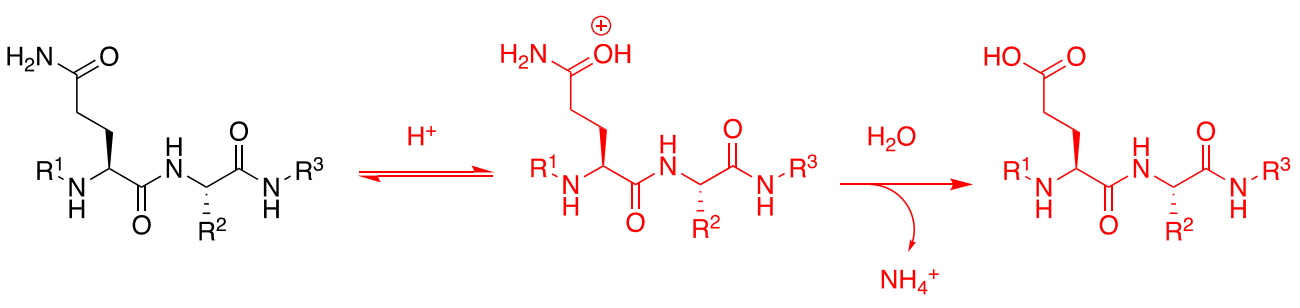

(b)

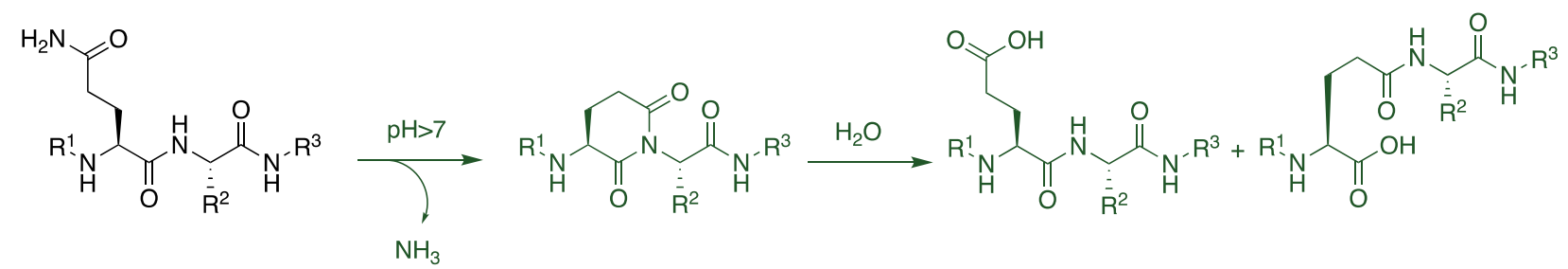

(c)<smiles>[R]NC(=O)[C@H]([R7])NC(=O)[C@H](N)CCC(N)=O</smiles>

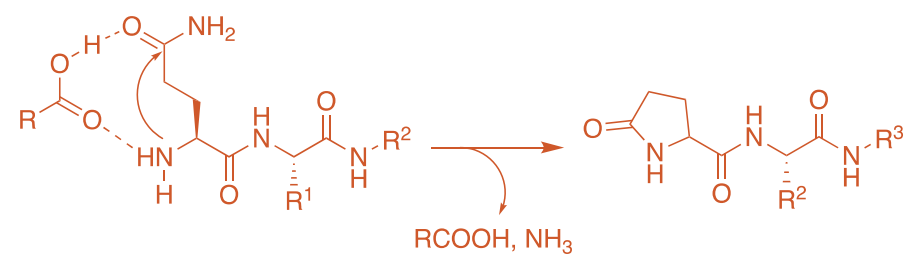

Scheme 11 Mechanisms of $\mathbf{a}, \mathbf{b}$ deamidation of Gln, and cyclization of N-terminal Gln

Scheme $12 \beta$-Elimination of Ser, Thr, Cys, and cystine

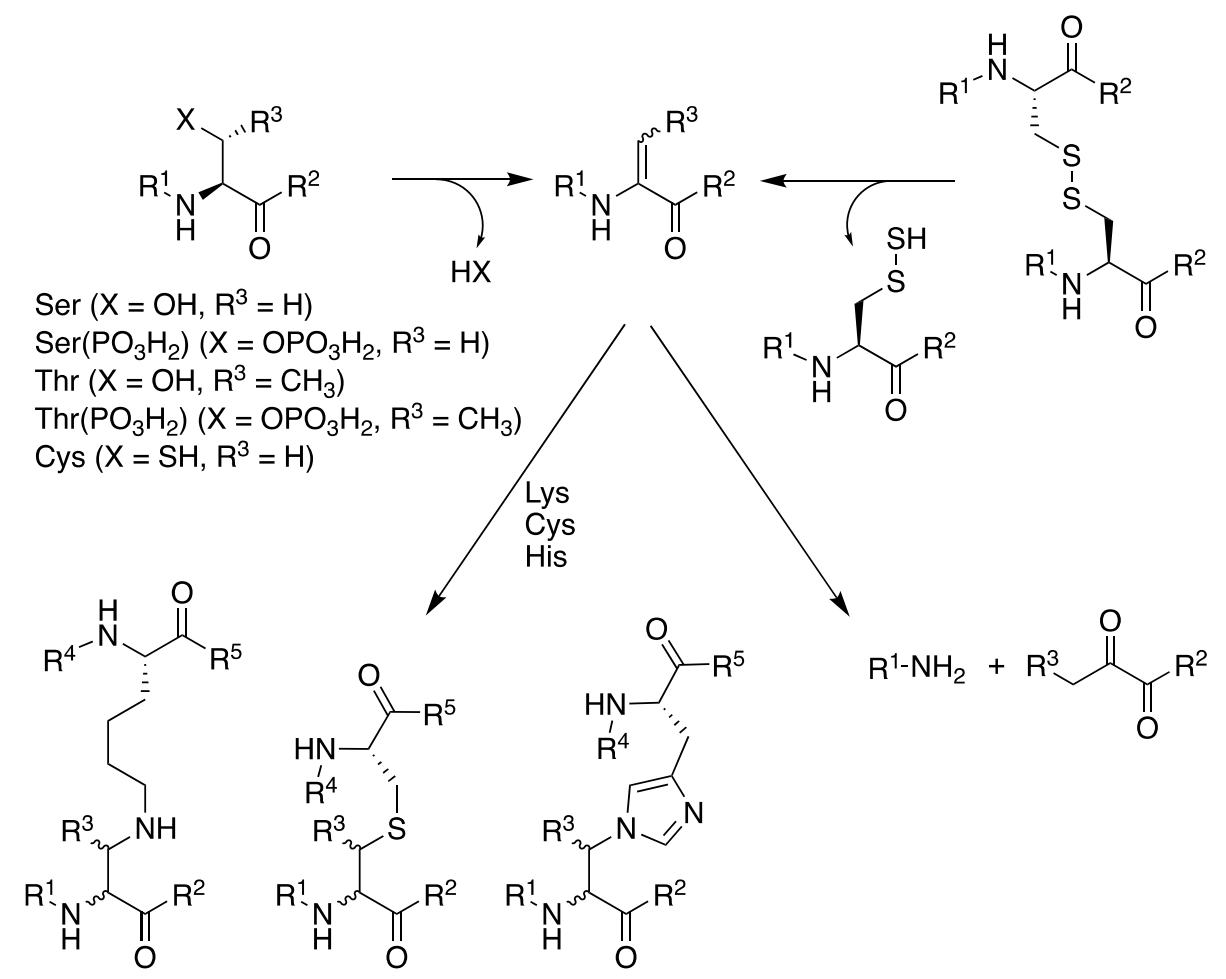

also of thiocysteine (Scheme 12) (Bar-Or et al. 2008; D'Hondt et al. 2014a). Due to the $s p^{2}$ hybridization of the $\alpha$-carbon, the $\alpha, \beta$-dehydro amino-acid residue has a planar geometry, which forces co-planarity of the two planar peptide units centered at the $s p^{2} \alpha$-carbon. This induces backbone conformations that are unusual for the native backbone (Ajo et al. 1980), which may influence the structural features of peptides and proteins (Palmer et al. 1992). Furthermore, due to the presence of the $\alpha, \beta$ unsaturated carbonyl moiety, $\alpha, \beta$-dehydro amino-acid 
residues enhance the reactivity of peptides and proteins: indeed, they may form covalent cross-linking via Michael addition of suitable nucleophiles like those of Lys, Cys, or His side chains, leading to lysinoalanine, lanthionine, and histidinoalanine linkages (Cohen et al. 2007; Costantino et al. 1994; Linetsky et al. 2004; Nashef et al. 1977), respectively. In addition, the by-product thiocysteine may trigger disulfide bonds reshuffling in cystine-containing peptides and proteins (Scheme 4) (Costantino et al. 1994).

Furthermore, $\Delta$ Ala derivatives may lead to backbone cleavage between the $\alpha \mathrm{N}$ and $\alpha \mathrm{C}$ of the $\Delta$ Ala residue, resulting in C-terminally amidated and $\mathrm{N}$-terminally pyruvoylated fragments (Cohen et al. 2007; D'Hondt et al. 2014b; Patchornik and Sokolovsky 1964; Sokolovsky et al. 1964; Wisniewski et al. 2013).

\section{Conclusions}

Spontaneous modifications of amino acids are a wellknown problem in peptide and protein research. However, it is obvious that they become very important, when peptides and proteins are used as drugs. In this case, the presence of spontaneous chemical changes and their biological effects must be carefully investigated (D'Hondt et al. 2014a; Wu et al. 2017). As a matter of fact, a lot of efforts are made to develop analytical tools and chemical protocols for the detection of spontaneous modifications in proteins and biopharmaceuticals (Alcock et al. 2018; Beck et al. 2013; Berkowitz et al. 2012; Forstenlehner et al. 2015; Grassi et al. 2017; Kettenhofen and Wood 2010; Regl et al. 2017; Schweida et al. 2019). Moreover, (semi)synthetic approaches are applied to reproduce proteins containing the spontaneous modification of interest at selected positions, to evaluate its impact on the protein structure and biology: for example, an explorative study has been conducted to assess the synthetic accessibility of the $\mathrm{Fc} \mathrm{CH} 3 \mathrm{IgG} 1$ region containing a modified residue, i.e., $\operatorname{Met}(\mathrm{O})$, at the desired position, to avoid the postproduction treatment with strong oxidants (Grassi et al. 2018). Furthermore, the semisynthetic approach has been used to prepare the two site-selective glycated proteins Hsp27 (Matveenko et al. 2016) and Tau (Ellmer et al. 2019): glycation refers to a class of non-enzymatic modifications of biomolecules containing nitrogen nucleophiles that react with the carbonyl group of ketoses or aldoses to build a Schiff base. The latter can slowly isomerize to the Amadori product (from aldoses) or Heyns-Carson product (from ketoses), which undergo further transformations to so-called advanced glycation end-products (AGEs), like argpyrimidine and $\mathrm{N} \varepsilon$-(carboxymethyl)-lysine. AGEs are believed to play a major role in aging and pathophysiological processes (Fournet et al. 2018). Hsp27 (heat-shock protein 27) is a chaperone protein that plays a role in the regulation of apoptosis in cancer cells, e.g., by inhibiting cytochrome $c$-mediated caspase activation and promoting cell survival. However, a glycated form of Hsp27 containing argpyrimidine at position 188 has been also isolated, which, contrarily to unmodified Hsp27, forms significantly smaller oligomers and is not able to counteract caspase activation by cytochrome $c$ (Sakamoto et al. 2002). Accordingly, the semisynthetic glycated variant has shown reduced chaperone activity in vitro (Matveenko et al. 2016). Tau is a protein that regulates microtubule assembly and disassembly in neurons and undergoes a number of PTMs, including phosphorylation and glycation, which may have an effect on its propensity to form pathogenic fibrils (Liu et al. 2016). A semisynthetic variant of Tau4 containing $\mathrm{N} \varepsilon$-(carboxymethyl)-lysine at position 294 has shown to negatively affect tubulin polymerization while displaying very similar fibrillization to the non-glycated variant, a behavior that has resulted to be opposite to that of phosphorylated Tau4 variants (Ellmer et al. 2019).

While many more spontaneous reactions of amino-acid residues are known than those mentioned, like reversible hydrogen-transfer reactions involving thiyl radicals in Cys-containing peptides and proteins (Mozziconacci et al. 2010, 2011; Steinmann et al. 2017), still many others are expected to occur, which will need to be detected and explored both mechanistically and biologically (Schöneich 2017). Future research in this field will enormously support the development of safe and potent peptide and protein drugs.

Acknowledgements Open access funding provided by Paris Lodron University of Salzburg. C. C. kindly acknowledges the Land Salzburg and the Paris Lodron University of Salzburg for financial support. The financial support by the Austrian Federal Ministry of Science, Research, and Economy and by a Startup Grant of the State of Salzburg is gratefully acknowledged.

\section{Compliance with ethical standards}

Conflict of interest The salary of L. G. was fully funded by the Christian Doppler Laboratory for Biosimilar Characterization, which is partly supported by Novartis and Thermo Fisher Scientific. The authors declare no other competing financial interest.

Research involving human participants This is a review paper without participation of humans.

Informed consent No inform consent was required (see above).

Open Access This article is distributed under the terms of the Creative Commons Attribution 4.0 International License (http://creativeco mmons.org/licenses/by/4.0/), which permits unrestricted use, distribution, and reproduction in any medium, provided you give appropriate 
credit to the original author(s) and the source, provide a link to the Creative Commons license, and indicate if changes were made.

\section{References}

Aeschbach R, Amado R, Neukom H (1976) Formation of dityrosine cross-links in proteins by oxidation of tyrosine residues. Biochim Biophys Acta 439:292-301

Agon VV, Bubb WA, Wright A, Hawkins CL, Davies MJ (2006) Sensitizer-mediated photooxidation of histidine residues: evidence for the formation of reactive side-chain peroxides. Free Radic Biol Med 40:698-710. https://doi.org/10.1016/j.freer adbiomed.2005.09.039

Ajo D, Granozzi G, Tondello E, Delpra A (1980) Conformational flexibility of peptides containing alpha, beta-unsaturated amino-acid-residues. 1. Conformational analysis of $\mathrm{N}$-acetyl$N^{\prime}$-methylamides of dehydroalanine and $N$-methyldehydroalanine. Biopolymers 19:469-475. https://doi.org/10.1002/ bip. 1980.360190303

Alcock LJ, Perkins MV, Chalker JM (2018) Chemical methods for mapping cysteine oxidation. Chem Soc Rev 47:231-268. https ://doi.org/10.1039/c7cs00607a

Ali FE, Barnham KJ, Barrow CJ, Separovic F (2004) Metal catalyzed oxidation of tyrosine residues by different oxidation systems of copper/hydrogen peroxide. J Inorg Biochem 98:173-184

Amano M, Kobayashi N, Yabuta M, Uchiyama S, Fukui K (2014) Detection of histidine oxidation in a monoclonal immunoglobulin gamma (IgG) 1 antibody. Anal Chem 86:7536-7543. https ://doi.org/10.1021/ac501300m

Ashraf CM, Ahmad I, Lugemwa FKN (1980) Kinetics and mechanism of the oxidation of L-phenylalanine by hydrogen-peroxide in the presence of ferrous sulfate as a catalyst. J Org Chem 45:3202-3204. https://doi.org/10.1021/jo01304a012

Aspee A, Lissi EA (2000) Kinetics and mechanism of the chemiluminescence associated with the free radical-mediated oxidation of amino acids. Luminescence 15:273-282. https://doi. org/10.1002/1522-7243

Aylin F, Konuklar S, Aviyente V (2003) Modelling the hydrolysis of succinimide: formation of aspartate and reversible isomerization of aspartic acid via succinimide. Org Biomol Chem 1:2290-2297

Baker MP, Reynolds HM, Lumicisi B, Bryson CJ (2010) Immunogenicity of protein therapeutics: the key causes, consequences and challenges. Self Nonself 1:314-322. https://doi. org/10.4161/self.1.4.13904

Bar-Or R, Rael LT, Bar-Or D (2008) Dehydroalanine derived from cysteine is a common post-translational modification inhuman serum albumin. Rapid Commun Mass Spectrom 22:711-716. https://doi.org/10.1002/rcm.3421

Bartelds GM et al (2011) Development of antidrug antibodies against adalimumab and association with disease activity and treatment failure during long-term follow-up. JAMA 305:14601468. https://doi.org/10.1001/jama.2011.406

Beck A, Wagner-Rousset E, Ayoub D, Van Dorsselaer A, SanglierCianferani S (2013) Characterization of therapeutic antibodies and related products. Anal Chem 85:715-736. https://doi. org/10.1021/ac3032355

Becker D, Swarts S, Champagne M, Sevilla MD (1988) An electronspin-resonance investigation of the reactions of glutathione, cysteine and penicillamine thiyl radicals - competitive formation of RSO, R', RSSR ${ }^{-}$, and RSS . Int J Radiat Biol 53:767786. https://doi.org/10.1080/09553008814551121
Behrendt R, White P, Offer J (2016) Advances in Fmoc solid-phase peptide synthesis. J Pept Sci 22:4-27. https://doi.org/10.1002/ psc. 2836

Benasson RV, Land EJ, Truscott TG (1983) Flash photolysis and pulse radiolysis: contributions to the chemistry of biology and medicine. Pergamon Press, Oxford

Bender NK, Heilig CE, Dröll B, Wohlgemuth J, Armbruster FP, Heilig B (2007) Immunogenicity, efficacy and adverse events of adalimumab in RA patients. Rheumatol Int 27:269-274. https://doi.org/10.1007/s00296-006-0183-7

Bent DV, Hayon E (1975) Excited-state chemistry of aromatic amino-acids and related peptides. 2. Phenylalanine. J Am Chem Soc 97:2606-2612. https://doi.org/10.1021/ja00843a003

Berkowitz SA, Engen JR, Mazzeo JR, Jones GB (2012) Analytical tools for characterizing biopharmaceuticals and the implications for biosimilars. Nat Rev Drug Discov 11:527-540. https ://doi.org/10.1038/nrd3746

Bertolotti-Ciarlet A et al (2009) Impact of methionine oxidation on the binding of human $\mathrm{IgG} 1$ to $\mathrm{Fc} \mathrm{Rn}$ and $\mathrm{Fc}$ gamma receptors. Mol Immunol 46:1878-1882. https://doi.org/10.1016/j.molim m.2009.02.002

Bielski BHJ, Cabelli DE, Arudi RL, Ross AB (1985) Reactivity of $\mathrm{HO}_{2} / \mathrm{O}_{2}{ }^{-}$radicals in aqueous-solution. J Phys Chem Ref Data 14:1041-1100. https://doi.org/10.1063/1.555739

Bloom JW, Madanat MS, Marriott D, Wong T, Chan SY (1997) Intrachain disulfide bond in the core hinge region of human IgG4. Protein Sci 6:407-415. https://doi.org/10.1002/pro.55600 60217

Bongers J et al (2000) Validation of a peptide mapping method for a therapeutic monoclonal antibody: what could we possibly learn about a method we have run 100 times? J Pharm Biomed Anal 21:1099-1128. https://doi.org/10.1016/s0731-7085(99)00181-8

Bonifacic M, Hug GL, Schöneich C (2000) Kinetics of the reactions between sulfide radical cation complexes, $[>\mathrm{S} \ldots \mathrm{S}<](+)$ and $[>$ $\mathrm{S}$... $\left.\mathrm{NH}_{2} \mathrm{R}\right](+)$, and superoxide or carbon dioxide radical anions. J Phys Chem A 104:1240-1245. https://doi.org/10.1021/jp993 4578

Brückner C, Fahr A, Imhof D, Scriba GK (2012) Degradation kinetics of an aspartyl-tripeptide-derived diketopiperazine under forced conditions. J Pharm Sci 101:4178-4190. https://doi.org/10.1002/ jps.23272

Büttel IC et al (2011) Taking immunogenicity assessment of therapeutic proteins to the next level. Biologicals 39:100-109. https://doi. org/10.1016/j.biologicals.2011.01.006

Capasso S, Mazzarella L, Sica F, Zagari A (1989) Deamidation via cyclic imide in asparaginyl peptides. Pept Res 2:195-200

Capasso S, Mazzarella L, Sica F, Zagari A (1991a) 1st Evidence of spontaneous deamidation of glutamine residue via cyclic imide to alpha-glutamic and gamma-glutamic residue under physiological conditions. J Chem Soc Chem Commun. https://doi. org/10.1039/c39910001667

Capasso S, Mazzarella L, Zagari A (1991b) Deamidation via cyclic imide of asparaginyl peptides: dependence on salts, buffers and organic solvents. Pept Res 4:234-238

Capasso S, Mazzarella L, Sica F, Zagari A, Salvadori S (1992) Spontaneous cyclization of the aspartic-acid side-chain to the succinimide derivative. J Chem Soc Chem Commun. https://doi. org/10.1039/c39920000919

Capasso S, Mazzarella L, Sica F, Zagari A, Salvadori S (1993) Kinetics and mechanism of succinimide ring formation in the deamidation process of asparagine residues. J Chem Soc Perkin Trans 2:679-682. https://doi.org/10.1039/P29930000679

Capasso S, Vergara A, Mazzarella L (1998) Mechanism of 2,5-dioxopiperazine formation. J Am Chem Soc 120:1990-1995. https:// doi.org/10.1021/ja972051a 
Chelius D, Rehder DS, Bondarenko PV (2005) Identification and characterization of deamidation sites in the conserved regions of human immunoglobulin gamma antibodies. Anal Chem 77:6004-6011. https://doi.org/10.1021/ac050672d

Chelius D et al (2006) Formation of pyroglutamic acid from N-terminal glutamic acid in immunoglobulin gamma antibodies. Anal Chem 78:2370-2376. https://doi.org/10.1021/ac051827k

Chu JW, Yin J, Brooks BR, Wang DI, Ricci MS, Brems DN, Trout BL (2004) A comprehensive picture of non-site specific oxidation of methionine residues by peroxides in protein pharmaceuticals. J Pharm Sci 93:3096-3102. https://doi.org/10.1002/ jps.20207

Chumsae C, Gaza-Bulseco G, Sun J, Liu H (2007) Comparison of methionine oxidation in thermal stability and chemically stressed samples of a fully human monoclonal antibody. J Chromatogr B Analyt Technol Biomed Life Sci 850:285-294. https://doi. org/10.1016/j.jchromb.2006.11.050

Clarke S (1987) Propensity for spontaneous succinimide formation from aspartyl and asparaginyl residues in cellular proteins. Int $\mathbf{J}$ Pept Protein Res 30:808-821

Cohen SL, Price C, Vlasak J (2007) Beta-elimination and peptide bond hydrolysis: two distinct mechanisms of human IgG1 hinge fragmentation upon storage. J Am Chem Soc 129:6976-6977. https ://doi.org/10.1021/ja0705994

Corthay A, Backlund J, Broddefalk J, Michaelsson E, Goldschmidt TJ, Kihlberg J, Holmdahl R (1998) Epitope glycosylation plays a critical role for $\mathrm{T}$ cell recognition of type II collagen in collagen-induced arthritis. Eur J Immunol 28:2580-2590. https:// doi.org/10.1002/(SICI)1521-4141(199808)28:08\%3c2580:AIDIMMU2580\%3e3.0.CO;2-X

Costantino HR, Langer R, Klibanov AM (1994) Moisture-induced aggregation of lyophilized insulin. Pharm Res 11:21-29. https ://doi.org/10.1023/A:1018981208076

Creed D (1984a) The photophysics and photochemistry of the near-UV absorbing amino-acids. 1. Tryptophan and its simple derivatives. Photochem Photobiol 39:537-562

Creed D (1984b) The photophysics and photochemistry of the near-UV absorbing amino-acids. 2. Tyrosine and its simple derivatives. Photochem Photobiol 39:563-575

d'Alessandro N, Bianchi G, Fang XW, Jin FM, Schuchmann HP, von Sonntag C (2000) Reaction of superoxide with phenoxyl-type radicals. J Chem Soc Perk Trans 2:1862-1867. https://doi. org/10.1039/b003346o

Darrington RT, Anderson BD (1994) The role of intramolecular nucleophilic catalysis and the effects of self-association on the deamidation of human insulin at low pH. Pharm Res 11:784-793

Davies MJ (2003) Singlet oxygen-mediated damage to proteins and its consequences. Biochem Biophys Res Commun 305:761-770

Davies MJ (2004) Reactive species formed on proteins exposed to singlet oxygen. Photochem Photobiol Sci 3:17-25. https://doi. org/10.1039/b307576c

Davies MJ, Gilbert BC (1992) ChemInform abstract: free radical reactions: fragmentation and rearrangements in aqueous solution. ChemInform 23:285. https://doi.org/10.1002/chin.199224285

Davies MJ, Truscott RJW (2001) Photo-oxidation of proteins and its role in cataractogenesis. J Photochem Photobiol B 63:114-125. https://doi.org/10.1016/S1011-1344(01)00208-1

Dehart MP, Anderson BD (2007) The role of the cyclic imide in alternate degradation pathways for asparagine-containing peptides and proteins. J Pharm Sci 96:2667-2685. https://doi.org/10.1002/ jps. 20905

D'Hondt M, Bracke N, Taevernier L, Gevaert B, Verbeke F, Wynendaele E, De Spiegeleer B (2014a) Related impurities in peptide medicines. J Pharm Biomed 101:2-30. https://doi.org/10.1016/j. jpba.2014.06.012
D'Hondt M, Fedorova M, Peng CY, Gevaert B, Taevernier L, Hoffmann R, De Spiegeleer B (2014b) Dry heat forced degradation of buserelin peptide: kinetics and degradant profiling. Int J Pharm 467:48-59. https://doi.org/10.1016/j.ijpharm.2014.03.043

Dick LWJ, Kim C, Qiu D, Cheng KC (2006) Determination of the origin of the $\mathrm{N}$-terminal pyro-glutamate variation in monoclonal antibodies using model peptides. Biotechnol Bioeng 97:544-553. https://doi.org/10.1002/bit.21260

Dillon TM et al (2008) Structural and functional characterization of disulfide isoforms of the human IgG2 subclass. J Biol Chem 283:16206-16215. https://doi.org/10.1074/jbc.m709988200

Dimarchi RD, Tam JP, Kent SB, Merrifield RB (1982) Weak acidcatalyzed pyrrolidone carboxylic acid formation from glutamine during solid phase peptide synthesis. Minimization by rapid coupling. Int J Pept Protein Res 19:88-93

Doyle HA, Mamula MJ (2012) Autoantigenesis: the evolution of protein modifications in autoimmune disease. Curr Opin Immunol 24:112-118. https://doi.org/10.1016/j.coi.2011.12.003

Doyle HA, Gee RJ, Mamula MJ (2007) Altered immunogenicity of isoaspartate containing proteins. Autoimmunity 40:131-137. https://doi.org/10.1080/08916930601165180

Ecker DM, Jones SD, Levine HL (2015) The therapeutic monoclonal antibody market. MAbs 7:9-14. https://doi.org/10.4161/19420 862.2015.989042

Eggleton P, Haigh R, Winyard PG (2008) Consequence of neo-antigenicity of the 'altered self'. Rheumatology (Oxford) 47:567571. https://doi.org/10.1093/rheumatology/ken014

Ehrenshaft M, Deterding LJ, Mason RP (2015) Tripping up Trp: modification of protein tryptophan residues by reactive oxygen species, modes of detection, and biological consequences. Free Radic Biol Med 89:220-228. https://doi.org/10.1016/j.freeradbio med.2015.08.003

Ellmer D, Brehs M, Haj-Yahya M, Lashuel HA, Becker CFW (2019) Single posttranslational modifications in the central repeat domains of Tau4 impact its aggregation and tubulin binding. Angew Chem Int Ed 58:1616-1620. https://doi.org/10.1002/ anie. 201805238

Finley EL, Dillon J, Crouch RK, Schey KL (1998) Identification of tryptophan oxidation products in bovine alpha-crystallin. Protein Sci 7:2391-2397. https://doi.org/10.1002/pro.5560071116

Fischer WH, Spiess J (1987) Identification of a mammalian glutaminyl cyclase converting glutaminyl into pyroglutamyl peptides. Proc Natl Acad Sci USA 84:3628-3632. https://doi.org/10.1073/ pnas.84.11.3628

Fornelli L et al (2012) Analysis of intact monoclonal antibody IgG1 by electron transfer dissociation Orbitrap FTMS. Mol Cell Proteomics 11:1758-1767. https://doi.org/10.1074/mcp.m112.019620

Forstenlehner IC, Holzmann J, Toll H, Huber CG (2015) Site-specific characterization and absolute quantification of pegfilgrastim oxidation by top-down high-performance liquid chromatography-mass spectrometry. Anal Chem 87:9336-9343. https://doi. org/10.1021/acs.analchem.5b02029

Fournet M, Bonte F, Desmouliere A (2018) Glycation damage: a possible hub for major pathophysiological disorders and aging. Aging Dis 9:880-900. https://doi.org/10.14336/AD.2017.1121

Garner B, Waldeck AR, Witting PK, Rye KA, Stocker R (1998) Oxidation of high density lipoproteins. II. Evidence for direct reduction of lipid hydroperoxides by methionine residues of apolipoproteins AI and AII. J Biol Chem 273:6088-6095

Garrison WM (1987) Reaction-mechanisms in the radiolysis of peptides, polypeptides, and proteins. Chem Rev 87:381-398. https ://doi.org/10.1021/cr00078a006

Gaza-Bulseco G, Faidu S, Hurkmans K, Chumsae C, Liu HC (2008) Effect of methionine oxidation of a recombinant monoclonal antibody on the binding affinity to protein $\mathrm{A}$ and protein 
G. J Chromatogr B 870:55-62. https://doi.org/10.1016/j.jchro $\mathrm{mb} .2008 .05 .045$

Geiger T, Clarke S (1987) Deamidation, isomerization, and racemization at asparaginyl and aspartyl residues in peptides. Succinimide-linked reactions that contribute to protein degradation. J Biol Chem 262:785-794

Ghogare AA, Greer A (2016) Using singlet oxygen to synthesize natural products and drugs. Chem Rev 116:9994-10034. https://doi. org/10.1021/acs.chemrev.5b00726

Gisin BF, Merrifield RB (1972) Carboxyl-catalyzed intramolecular aminolysis. A side reaction in solid-phase peptide synthesis. J Am Chem Soc 94:3102-3106

Goolcharran C, Borchardt RT (1998) Kinetics of diketopiperazine formation using model peptides. J Pharm Sci 87:283-288. https:// doi.org/10.1021/js970325m

Goolcharran C, Stauffer LL, Cleland JL, Borchardt RT (2000) The effects of a histidine residue on the $\mathrm{C}$-terminal side of an asparaginyl residue on the rate of deamidation using model pentapeptides. J Pharm Sci 89:818-825. https://doi.org/10.1002/ (SICI) 1520-6017

Gracanin M, Hawkins CL, Pattison DI, Davies MJ (2009) Singletoxygen-mediated amino acid and protein oxidation: formation of tryptophan peroxides and decomposition products. Free Radic Biol Med 47:92-102. https://doi.org/10.1016/j.freeradbio med.2009.04.015

Grassi L, Regl C, Wildner S, Gadermaier G, Huber CG, Cabrele C, Schubert M (2017) Complete NMR assignment of succinimide and its detection and quantification in peptides and intact proteins. Anal Chem 89:11962-11970. https://doi.org/10.1021/acs. analchem.7b01645

Grassi L, Roschger C, Stanojlovic V, Cabrele C (2018) An explorative study towards the chemical synthesis of the immunoglobulin G1 Fc CH3 domain. J Pept Sci 24:e3126. https://doi.org/10.1002/ psc. 3126

$\mathrm{Gu} \mathrm{S}$ et al (2010) Characterization of trisulfide modification in antibodies. Anal Biochem 400:89-98. https://doi.org/10.1016/j. ab.2010.01.019

Harris RJ et al (2001) Identification of multiple sources of charge heterogeneity in a recombinant antibody. J Chromatogr B Biomed Sci Appl 752:233-245

Hawe A, Poole R, Romeijn S, Kasper P, van der Heijden R, Jiskoot W (2009) Towards heat-stable oxytocin formulations: analysis of degradation kinetics and identification of degradation products. Pharm Res 26:1679-1688. https://doi.org/10.1007/s1109 5-009-9878-2

Hensel $\mathrm{M}$ et al (2011) Identification of potential sites for tryptophan oxidation in recombinant antibodies using tert-butylhydroperoxide and quantitative LC-MS. PLoS One 6:e17708. https://doi. org/10.1371/journal.pone.0017708

Hovorka SW, Biesiada H, Williams TD, Huhmer A, Schöneich C (2002) High sensitivity of $\mathrm{Zn}^{2+}$ insulin to metal-catalyzed oxidation: detection of 2-oxo-histidine by tandem mass spectrometry. Pharm Res 19:530-537. https://doi.org/10.1023/a:1015164200 431

Hsu YR, Narhi LO, Spahr C, Langley KE, Lu HS (1996) In vitro methionine oxidation of Escherichia coli-derived human stem cell factor: effects on the molecular structure, biological activity, and dimerization. Protein Sci 5:1165-1173. https://doi. org/10.1002/pro.5560050619

Huang L, Lu J, Wroblewski VJ, Beals JM, Riggin RM (2005) In vivo deamidation characterization of monoclonal antibody by LC/MS/ MS. Anal Chem 77:1432-1439. https://doi.org/10.1021/ac049 4174

Hudson DA, Gannon SA, Thorpe C (2015) Oxidative protein folding: from thiol-disulfide exchange reactions to the redox poise of the endoplasmic reticulum. Free Radic Biol Med 80:171-182. https ://doi.org/10.1016/j.freeradbiomed.2014.07.037

Huvaere K, Skibsted LH (2009) Light-induced oxidation of tryptophan and histidine. Reactivity of aromatic $N$-heterocycles toward triplet-excited flavins. J Am Chem Soc 131:8049-8060. https:// doi.org/10.1021/ja809039u

Ito S, Kato T, Shinpo K, Fujita K (1984) Oxidation of tyrosine residues in proteins by tyrosinase. Formation of protein-bonded 3,4-dihydroxyphenylalanine and 5-S-cysteinyl-3,4-dihydroxyphenylalanine. Biochem J 222:407-411

Ito S, Kato T, Fujita K (1988) Covalent binding of catechols to proteins through the sulphydryl group. Biochem Pharmacol $37: 1707-1710$

Jin Y et al (2019) Comprehensive characterization of monoclonal antibody by Fourier transform ion cyclotron resonance mass spectrometry. MAbs 11:106-115. https://doi. org/10.1080/19420862.2018.1525253

Jordan GM, Yoshioka S, Terao T (1994) The aggregation of bovine serum-albumin in solution and in the solid-state. J Pharm Pharmacol 46:182-185. https://doi.org/10.1111/j.2042-7158.1994. tb03774.x

Jornvall H (1974) Blocked alpha-amino groups in peptides due to diketopiperazine formation. FEBS Lett 38:329-333. https:// doi.org/10.1016/0014-5793(74)80084-0

Joshi AB, Sawai M, Kearney WR, Kirsch LE (2005) Studies on the mechanism of aspartic acid cleavage and glutamine deamidation in the acidic degradation of glucagon. J Pharm Sci 94:1912-1927. https://doi.org/10.1002/jps.20405

Juran JM (1992) Quality by design: the new steps for planning quality into goods and services. Free Press, New York

Kang H, Tolbert TJ, Schöneich C (2019) Photoinduced tyrosine side chain fragmentation in IgG4-Fc: mechanisms and solvent isotope effects. Mol Pharm 16:258-272. https://doi.org/10.1021/ acs.molpharmaceut.8b00979

Kettenhofen NJ, Wood MJ (2010) Formation, reactivity, and detection of protein sulfenic acids. Chem Res Toxicol 23:16331646. https://doi.org/10.1021/tx100237w

Khawli LA et al (2010) Charge variants in IgG1: isolation, characterization, in vitro binding properties and pharmacokinetics in rats. MAbs 2:613-624. https://doi.org/10.4161/mabs.2.6.13333

Krishna M, Nadler SG (2016) Immunogenicity to biotherapeuticsthe role of anti-drug immune complexes. Front Immunol 7:21. https://doi.org/10.3389/fimmu.2016.00021

Krokhin OV, Antonovici M, Ens W, Wilkins JA, Standing KG (2006) Deamidation of -Asn-Gly- sequences during sample preparation for proteomics: consequences for MALDI and HPLC-MALDI analysis. Anal Chem 78:6645-6650. https:// doi.org/10.1021/ac061017o

Kumar A, Bachhawat AK (2012) Pyroglutamic acid: throwing light on a lightly studied metabolite. Curr Sci India 102:288-297

Kuriakose A, Chirmule N, Nair P (2016) Immunogenicity of biotherapeutics: causes and association with posttranslational modifications J. Immunol Res 2016:1298473

Lam XM, Yang JY, Cleland JL (1997) Antioxidants for prevention of methionine oxidation in recombinant monoclonal antibody HER2. J Pharm Sci 86:1250-1255. https://doi.org/10.1021/ js970143s

Lampi KJ, Amyx KK, Ahmann P, Steel EA (2006) Deamidation in human lens $\beta$ B2-crystallin destabilizes the dimer. Biochemistry 45:3146-3153. https://doi.org/10.1021/bi052051k

Langlots R, Ali H, Brasseur N, Wagner JR, van Lier JE (1986) Biological activities of phythalocyanines-IV. Type II sensitized photooxidation of L-tryptophan and cholesterol by sulfonated metallo phthalocyanines. Photochem Photobiol 44:117-123

Lau JL, Dunn MK (2018) Therapeutic peptides: historical perspectives, current development trends, and future directions. 
Bioorg Med Chem 26:2700-2707. https://doi.org/10.1016/j. bmc.2017.06.052

Lei $M$ et al (2017) Structure-based correlation of light-induced histidine reactivity in a model protein. Anal Chem 89:7225-7231. https://doi.org/10.1021/acs.analchem.7b01457

Lermyte F, Tsybin YO, O'Connor PB, Loo JA (2019) Top or middle? Up or down? Toward a standard lexicon for protein top-down and allied mass spectrometry approaches. J Am Soc Mass Spectrom 30:1149-1157. https://doi.org/10.1007/s13361-019-02201-x

Li SH, Schöneich C, Borchardt RT (1995) Chemical-instability of protein pharmaceuticals - mechanisms of oxidation and strategies for stabilization. Biotechnol Bioeng 48:490-500. https://doi. org/10.1002/bit.260480511

Li YM, Polozova A, Gruia F, Feng JH (2014) Characterization of the degradation products of a color-changed monoclonal antibody: tryptophan-derived chromophores. Anal Chem 86:6850-6857. https://doi.org/10.1021/ac404218t

Linetsky M, Hill JMW, LeGrand RD, Hu F (2004) Dehydroalanine crosslinks in human lens. Exp Eye Res 79:499-512. https://doi. org/10.1016/j.exer.2004.06.026

Liu D et al (2008) Structure and stability changes of human IgG1 Fc as a consequence of methionine oxidation. Biochemistry 47:50885100. https://doi.org/10.1021/bi7o2238b

Liu YD, Goetze AM, Bass RB, Flynn GC (2011) N-terminal glutamate to pyroglutamate conversion in vivo for human $\mathrm{IgG} 2$ antibodies. J Biol Chem 286:11211-11217. https://doi.org/10.1074/jbc. m110.185041

Liu FW, Lu WC, Fang YG, Liu JB (2014a) Evolution of oxidation dynamics of histidine: non-reactivity in the gas phase, peroxides in hydrated clusters, and $\mathrm{pH}$ dependence in solution. Phys Chem Chem Phys 16:22179-22191. https://doi.org/10.1039/ $\mathrm{c} 4 \mathrm{cp} 03550 \mathrm{j}$

Liu M, Zhang Z, Cheetham J, Ren D, Zhou ZS (2014b) Discovery and characterization of a photo-oxidative histidine-histidine crosslink in IgG1 antibody utilizing ${ }^{18} \mathrm{O}$-labeling and mass spectrometry. Anal Chem 86:4940-4948. https://doi.org/10.1021/ac500 $334 \mathrm{k}$

Liu K, Liu Y, Li L, Qin P, Iqbal J, Deng Y, Qing H (2016) Glycation alter the process of Tau phosphorylation to change Tau isoforms aggregation property. Biochim Biophys Acta 1862:192-201. https://doi.org/10.1016/j.bbadis.2015.12.002

Luo Q, Joubert MK, Stevenson R, Ketchem RR, Narhi LO, Wypych J (2011) Chemical modifications in therapeutic protein aggregates generated under different stress conditions. J Biol Chem 286:25134-25144. https://doi.org/10.1074/jbc.M110.160440

Lyubarskaya Y, Houde D, Woodard J, Murphy D, Mhatre R (2006) Analysis of recombinant monoclonal antibody isoforms by electrospray ionization mass spectrometry as a strategy for streamlining characterization of recombinant monoclonal antibody charge heterogeneity. Anal Biochem 348:24-39. https://doi. org/10.1016/j.ab.2005.10.003

Mallagaray A et al (2019) A post-translational modification of human Norovirus capsid protein attenuates glycan binding. Nature Communications 10:1320. https://doi.org/10.1038/s41467-019-09251 $-5$

Mamula MJ, Gee RJ, Elliott JI, Sette A, Southwood S, Jones PJ, Blier PR (1999) Isoaspartyl post-translational modification triggers autoimmune responses to self-proteins. J Biol Chem 274:2232122327. https://doi.org/10.1074/jbc.274.32.22321

Mao Y, Valeja SG, Rouse JC, Hendrickson CL, Marshall AG (2013) Top-down structural analysis of an intact monoclonal antibody by electron capture dissociation-Fourier transform ion cyclotron resonance-mass spectrometry. Anal Chem 85:4239-4246. https ://doi.org/10.1021/ac303525n

Marcus F (1985) Preferential cleavage at aspartyl-prolyl peptide bonds in dilute acid. Int J Pept Protein Res 25:542-546
Martinez T et al (2008) Disulfide connectivity of human immunoglobulin G2 structural isoforms. Biochemistry 47:7496-7508. https:// doi.org/10.1021/bi800576c

Matveenko M, Cichero E, Fossa P, Becker CF (2016) Impaired chaperone activity of human heat shock protein Hsp27 site-specifically modified with argpyrimidine. Angew Chem Int Ed 55:1139711402. https://doi.org/10.1002/anie.201605366

Millington KR, Church JS (1997) The photodegradation of wool keratin. 2. Proposed mechanisms involving cystine. J Photochem Photobiol B 39:204-212. https://doi.org/10.1016/S1011 -1344(96)00020-6

Moller MN, Hatch DM, Kim HY, Porter NA (2012) Superoxide reaction with tyrosyl radicals generates para-hydroperoxy and parahydroxy derivatives of tyrosine. J Am Chem Soc 134:1677316780. https://doi.org/10.1021/ja307215z

Montes-Cortes DH, Hicks JJ, Ceballos-Reyes GM, Garcia-Sanchez JR, Medina-Navarro R, Olivares-Corichi IM (2010) Chemical and functional changes of human insulin by in vitro incubation with blood from diabetic patients in oxidative stress. Metabolism 59:935-942. https://doi.org/10.1016/j.metabol.2009.10.013

Moorhouse KG, Nashabeh W, Deveney J, Bjork NS, Mulkerrin MG, Ryskamp T (1997) Validation of an HPLC method for the analysis of the charge heterogeneity of the recombinant monoclonal antibody IDEC-C2B8 after papain digestion. J Pharm Biomed 16:593-603. https://doi.org/10.1016/s0731-7085(97)00178-7

Moroder L, Buchner J (2008) Oxidative folding of peptides and proteins (RSC Biomolecular Sciences). RSC Publishing, Cambridge

Mozziconacci O, Kerwin BA, Schöneich C (2010) Reversible hydrogen transfer between cysteine thiyl radical and glycine and alanine in model peptides: covalent H/D exchange, radical-radical reactions, and L- to D-Ala conversion. J Phys Chem B 114:67516762. https://doi.org/10.1021/jp101508b

Mozziconacci O, Kerwin BA, Schöneich C (2011) Reversible hydrogen transfer reactions of cysteine thiyl radicals in peptides: the conversion of cysteine into dehydroalanine and alanine, and of alanine into dehydroalanine. J Phys Chem B 115:12287-12305. https://doi.org/10.1021/jp2070453

Mozziconacci O, Ji JA, Wang YJ, Schöneich C (2013) Metal-catalyzed oxidation of protein methionine residues in human parathyroid hormone (1-34): formation of homocysteine and a novel methionine-dependent hydrolysis reaction. Mol Pharm 10:739-755. https://doi.org/10.1021/mp300563m

Mozziconacci O, Okbazghi S, More AS, Volkin DB, Tolbert T, Schoneich C (2016a) Comparative evaluation of the chemical stability of 4 well-defined immunoglobulin G1-Fc glycoforms. J Pharm Sci 105:575-587. https://doi.org/10.1016/j.xphs.2015.10.024

Mozziconacci O, Arora J, Toth RT, Joshi SB, Zhou S, Volkin DB, Schöneich C (2016b) Site-specific hydrolysis reaction $C$-terminal of methionine in Met-His during metal-catalyzed oxidation of IgG-1. Mol Pharm 13:1317-1328. https://doi.org/10.1021/acs. molpharmaceut.5b00944

Mukherjee R, Adhikary L, Khedkar A, Iyer H (2010) Probing deamidation in therapeutic immunoglobulin gamma (IgG1) by 'bottomup' mass spectrometry with electron transfer dissociation. Rapid Commun Mass Spectrom 24:879-884. https://doi.org/10.1002/ rcm.4464

Mulinacci F, Capelle MA, Gurny R, Drake AF, Arvinte T (2011) Stability of human growth hormone: influence of methionine oxidation on thermal folding. J Pharm Sci 100:451-463

Mulinacci F, Poirier E, Capelle MA, Gurny R, Arvinte T (2013) Influence of methionine oxidation on the aggregation of recombinant human growth hormone. Eur J Pharm Biopharm 85:42-52. https ://doi.org/10.1016/j.ejpb.2013.03.015

Nakagawa M, Watanabe H, Kodato S, Okajima H, Hino T, Flippen JL, Witkop B (1977) A valid model for the mechanism of oxidation 
of tryptophan to formylkynurenine-25 years later. Proc Natl Acad Sci USA 74:4730-4733

Nashef AS, Osuga DT, Lee HS, Ahmed AI, Whitaker JR, Feeney RE (1977) Effects of alkali on proteins - disulfides and their products. J Agric Food Chem 25:245-251. https://doi.org/10.1021/ jf60210a020

Nicolardi S, Deelder AM, Palmblad M, van der Burgt YE (2014) Structural analysis of an intact monoclonal antibody by online electrochemical reduction of disulfide bonds and Fourier transform ion cyclotron resonance mass spectrometry. Anal Chem 86:5376-5382. https://doi.org/10.1021/ac500383c

Nielsen RW, Tachibana C, Hansen NE, Winther JR (2011) Trisulfides in proteins. Antioxid Redox Signal 15:67-75. https://doi. org/10.1089/ars.2010.3677

Okamoto K, Kadowaki T, Nakayama K, Yamamoto K (1996) Cloning and sequencing of the gene encoding a novel lysine-specific cysteine proteinase (Lys-gingipain) in Porphyromonas gingivalis: structural relationship with the arginine-specific cysteine proteinase (Arg-gingipain). J Biochem 120:398-406. https:// doi.org/10.1093/oxfordjournals.jbchem.a021426

Olivares-Corichi IM, Ceballos G, Medina-Santillan R, Medina-Navarro R, Guzman-Grenfell AM, Hicks JJ (2005) Oxidation by reactive oxygen species (ROS) alters the structure of human insulin and decreases the insulin-dependent D-glucose- $\mathrm{C}^{14}$ utilization by human adipose tissue. Front Biosci 10:3127-3131

Oliyai C, Borchardt RT (1993) Chemical pathways of peptide degradation. IV. Pathways, kinetics, and mechanism of degradation of an aspartyl residue in a model hexapeptide. Pharm Res 10:95-102

Oyler AR, Naldi RE, Lloyd JR, Graden DA, Shaw CJ, Cotter ML (1991) Characterization of the solution degradation products of histrelin, a gonadotropin-releasing-hormone (Lh Rh) agonist. J Pharm Sci 80:271-275. https://doi.org/10.1002/jps.2600800316

Palmer DE et al (1992) Effects of dehydroalanine on peptide conformations. J Am Chem Soc 114:5634-5642. https://doi.org/10.1021/ ja00040a024

Pan H, Chen K, Chu LP, Kinderman F, Apostol I, Huang G (2009) Methionine oxidation in human IgG2 Fc decreases binding affinities to protein A and FcRn. Prot Sci 18:424-433. https://doi. org/10.1002/pro.45

Pascual-Salcedo D et al (2011) Influence of immunogenicity on the efficacy of long-term treatment with infliximab in rheumatoid arthritis. Rheumatology (Oxford) 50:1445-1452. https://doi. org/10.1093/rheumatology/ker124

Patchornik A, Sokolovsky M (1964) Nonenzymatic cleavages of peptide chains at cysteine and serine residues through their conversion into dehydroalanine. 1. Hydrolytic and oxidative cleavage of dehydroalanine residues. J Am Chem Soc 86:1206-1212. https ://doi.org/10.1021/ja01060a049

Patel K, Borchardt RT (1990a) Chemical pathways of peptide degradation. II. Kinetics of deamidation of an asparaginyl residue in a model hexapeptide. Pharm Res 7:703-711

Patel K, Borchardt RT (1990b) Chemical pathways of peptide degradation. III. Effect of primary sequence on the pathways of deamidation of asparaginyl residues in hexapeptides. Pharm Res 7:787-793

Pattison DI, Rahmanto AS, Davies MJ (2012) Photo-oxidation of proteins. Photochem Photobiol Sci 11:38-53. https://doi. org/10.1039/c1pp05164d

Pedzinski T, Markiewicz A, Marciniak B (2009) Photosensitized oxidation of methionine derivatives. Laser flash photolysis studies. Res Chem Intermediat 35:497-506. https://doi.org/10.1007/ s11164-009-0046-4

Perez-Garmendia R, Gevorkian G (2013) Pyroglutamate-modified amyloid beta peptides: emerging targets for Alzheimer's disease immunotherapy. Curr Neuropharmacol 11:491-498. https://doi. org/10.2174/1570159x11311050004

Pigault C, Gerard D (1984) Influence of the location of tryptophanyl residues in proteins on their photosensitivity. Photochem Photobiol 40:291-297. https://doi.org/10.1111/j.1751-1097.1984. tb04590.x

Pineda C, Castaneda Hernandez G, Jacobs IA, Alvarez DF, Carini C (2016) Assessing the immunogenicity of biopharmaceuticals. BioDrugs 30:195-206. https://doi.org/10.1007/s4025 9-016-0174-5

Radkiewicz JL, Zipse H, Clarke S, Houk KN (1996) Accelerated racemization of aspartic acid and asparagine residues via succinimide intermediates: an ab initio theoretical exploration of mechanism. J Am Chem Soc 118:9148-9155. https://doi.org/10.1021/ja953 $505 \mathrm{~b}$

Regl C, Wohlschlager T, Holzmann J, Huber CG (2017) A generic HPLC method for absolute quantification of oxidation in monoclonal antibodies and $\mathrm{Fc}$-fusion proteins using UV and MS detection. Anal Chem 89:8391-8398. https://doi.org/10.1021/ acs.analchem.7b01755

Rehder DS, Dillon TM, Pipes GD, Bondarenko PV (2006) Reversedphase liquid chromatography/mass spectrometry analysis of reduced monoclonal antibodies in pharmaceutics. J Chromatogr A 1102:164-175. https://doi.org/10.1016/j.chroma.2005.10.053

Reissner KJ, Aswad DW (2003) Deamidation and isoaspartate formation in proteins: unwanted alterations or surreptitious signals? Cell Mol Life Sci 60:1281-1295. https://doi.org/10.1007/s0001 8-003-2287-5

Rink R et al (2010) To protect peptide pharmaceuticals against peptidases. J Pharmacol Toxicol Methods 61:210-218. https://doi. org/10.1016/j.vascn.2010.02.010

Rizzuto F, Spikes JD (1977) The eosin-sensitized photooxidation of substituted phenylalanines and tyrosines. Photochem Photobiol 25:465-476

Robinson AB, Rudd CJ (1974) Deamidation of glutaminyl and asparaginyl residues in peptides and proteins. Curr Top Cell Regul $8: 247-295$

Robinson AB, Scotchle JW, Mckerrow JH (1973) Rates of nonenzymatic deamidation of glutaminyl and asparaginyl residues in pentapeptides. J Am Chem Soc 95:8156-8160. https://doi. org/10.1021/ja00805a032

Robinson NE, Robinson ZW, Robinson BR, Robinson AL, Robinson JA, Robinson ML, Robinson AB (2004) Structure-dependent nonenzymatic deamidation of glutaminyl and asparaginyl pentapeptides. J Pept Res 63:426-436. https://doi.org/10.111 1/j.1399-3011.2004.00151.x

Rogstad S, Faustino A, Ruth A, Keire D, Boyne M, Park J (2017) A retrospective evaluation of the use of mass spectrometry in FDA biologics license applications. J Am Soc Mass Spectrom 28:786-794. https://doi.org/10.1007/s13361-016-1531-9

Russo C et al (2002) Pyroglutamate-modified amyloid $\beta$-peptides$\mathrm{A} \beta \mathrm{N} 3(\mathrm{pE})$ - strongly affect cultured neuron and astrocyte survival. J Neurochem 82:1480-1489. https://doi.org/10.104 6/j.1471-4159.2002.01107.x

Sadineni V, Schöneich C (2007) Selective oxidation of $\mathrm{Zn}^{2+}$-insulin catalyzed by $\mathrm{Cu}^{2+}$. J Pharm Sci 96:1844-1847. https://doi. org/10.1002/jps.20834

Saito I, Matsuura T, Nakagawa M, Hino T (1977) Peroxidic intermediates in photosensitized oxygenation of tryptophan derivatives. Acc Chem Res 10:3346-3352

Sakamoto H, Mashima T, Yamamoto K, Tsuruo T (2002) Modulation of heat-shock protein 27 (Hsp27) anti-apoptotic activity by methylglyoxal modification. J Biol Chem 277:45770-45775. https:// doi.org/10.1074/jbc.m207485200

Schilling S, Hoffmann T, Manhart S, Hoffmann M, Demuth HU (2004) Glutaminyl cyclases unfold glutamyl cyclase activity 
under mild acid conditions. FEBS Lett 563:191-196. https:// doi.org/10.1016/S0014-5793(04)00300-X

Schilling S et al (2008) Glutaminyl cyclase inhibition attenuates pyroglutamate Abeta and Alzheimer's disease-like pathology. Nat Med 14:1106-1111. https://doi.org/10.1038/nm.1872

Schlenzig D et al (2009) Pyroglutamate formation influences solubility and amyloidogenicity of amyloid peptides. Biochemistry 48:7072-7078. https://doi.org/10.1021/bi900818a

Schon I, Kisfaludy L (1979) Formation of aminosuccinyl peptides during acidolytic deprotection followed by their transformation to piperazine-2,5-dione derivatives in neutral media. Int J Pept Prot Res 14:485-494

Schöneich C (2000) Mechanisms of metal-catalyzed oxidation of histidine to 2-oxo-histidine in peptides and proteins. J Pharm Biomed Anal 21:1093-1097

Schöneich C (2005) Methionine oxidation by reactive oxygen species: reaction mechanisms and relevance to Alzheimer's disease. Biochim Biophys Acta 1703:111-119. https://doi.org/10.1016/j. bbapap.2004.09.009

Schöneich C (2012) Radical-based damage of sulfur-containing amino acid residues. Encycl Radic Chem Biol Mater. https:// doi.org/10.1002/9780470971253.rad044

Schöneich C (2016) Thiyl radicals and induction of protein degradation. Free Radic Res 50:143-149. https://doi.org/10.3109/10715 762.2015 .1077385

Schöneich C (2017) Sulfur radical-induced redox modifications in proteins: analysis and mechanistic aspects. Antioxid Redox Signal 26:388-405. https://doi.org/10.1089/ars.2016.6779

Schöneich C (2018) Novel chemical degradation pathways of proteins mediated by tryptophan oxidation: tryptophan side chain fragmentation. J Pharm Pharmacol 70:655-665. https://doi. org/10.1111/jphp.12688

Schöneich C, Aced A, Asmus KD (1993) Mechanism of oxidation of aliphatic thioethers to sulfoxides by hydroxyl radicals- the importance of molecular-oxygen. J Am Chem Soc 115:1137611383. https://doi.org/10.1021/ja00077a042

Schöneich C, Zhao F, Madden KP, Bobrowski K (1994) Side-chain fragmentation of $\mathrm{N}$-terminal threonine or serine residue induced through intramolecular proton-transfer to hydroxy sulfuranyl radical formed at neighboring methionine in dipeptides. J Am Chem Soc 116:4641-4652. https://doi.org/10.1021/ja00090a012

Schuurman J, Van Ree R, Perdok GJ, Van Doorn HR, Tan KY, Aalberse RC (1999) Normal human immunoglobulin G4 is bispecific: it has two different antigen-combining sites. Immunology 97:693-698

Schuurman J, Perdok GJ, Gorter AD, Aalberse RC (2001) The interheavy chain disulfide bonds of IgG4 are in equilibrium with intra-chain disulfide bonds. Mol Immunol 38:1-8

Schweida D, Barraud P, Regl C, Loughlin FE, Huber CG, Cabrele C, Schubert M (2019) The NMR signature of gluconoylation: a frequent $\mathrm{N}$-terminal modification of isotope-labeled proteins. J Biomol NMR 73:71-79. https://doi.org/10.1007/s10858-01900228-6

Scotchler JW, Robinson AB (1974) Deamidation of glutaminyl residues-dependence on $\mathrm{pH}$, temperature, and ionic-strength. Anal Biochem 59:319-322. https://doi.org/10.1016/00032697(74)90040-2

Scott CF, Whitaker EJ, Hammond BF, Colman RW (1993) Purification and characterization of a potent $70-\mathrm{kDa}$ thiol lysyl-proteinase (Lys-gingivain) from Porphyromonas gingivalis that cleaves kininogens and fibrinogen. J Biol Chem 268:7935-7942

Sepetov NF, Krymsky MA, Ovchinnikov MV, Bespalova ZD, Isakova OL, Soucek M, Lebl M (1991) Rearrangement, racemization and decomposition of peptides in aqueous solution. Pept Res $4: 308-313$
Sevilla MD, Yan MY, Becker D (1988) Thiol peroxyl radical formation from the reaction of cysteine thiyl radical with molecularoxygen - an electron-spin-resonance investigation. Biochem Biophis Res Commun 155:405-410. https://doi.org/10.1016/ S0006-291x(88)81100-8

Sharov VS, Ferrington DA, Squier TC, Schöneich C (1999) Diastereoselective reduction of protein-bound methionine sulfoxide by methionine sulfoxide reductase. FEBS Lett 455:247-250

Shen FJ, Kwong MY, Keck RG, Harris RJ (1996) The application of tert-butylhydroperoxide oxidation to study sites of potential methionine oxidation in a recombinant antibody. In: Techniques in protein chemistry VII. Academic Press Inc., New York, pp. $275-284$

Shields RL et al (2001) High resolution mapping of the binding site on human IgG1 for Fc gamma RI, Fc gamma RII, Fc gamma RIII, and FcRn and design of IgG1 variants with improved binding to the Fc gamma R. J Biol Chem 276:6591-6604. https://doi. org/10.1074/jbc.m009483200

Silva E et al (2019) Riboflavin-induced type 1 photo-oxidation of tryptophan using a high intensity $365 \mathrm{~nm}$ light emitting diode. Free Radic Biol Med 131:133-143. https://doi.org/10.1016/j.freer adbiomed.2018.11.026

Sinha S, Zhang L, Duan S, Williams TD, Vlasak J, Ionescu R, Topp EM (2009) Effect of protein structure on deamidation rate in the Fc fragment of an IgG1 monoclonal antibody. Protein Sci 18:1573-1584. https://doi.org/10.1002/pro.173

Sokolovsky M, Sadeh T, Patchornik A (1964) Nonenzymatic cleavages of peptide chains at cysteine and serine residues through their conversion to dehydroalanine (DHAL). 2. Specific chemical cleavage of cysteinyl peptides. J Am Chem Soc 86:1212-1217

Song Y, Buettner GR (2010) Thermodynamic and kinetic considerations for the reaction of semiquinone radicals to form superoxide and hydrogen peroxide. Free Radic Biol Med 49:919-962. https ://doi.org/10.1016/j.freeradbiomed.2010.05.009

Steinberg S, Bada JL (1981) Diketopiperazine formation during investigations of amino acid racemization in dipeptides. Science 213:544-545. https://doi.org/10.1126/science.213.4507.544

Steinberg SM, Bada JL (1983) Peptide decomposition in the neutral $\mathrm{pH}$-region via the formation of diketopiperazines. J Org Chem 48:2295-2298. https://doi.org/10.1021/jo00161a036

Steinmann D, Mozziconacci O, Bommana R, Stobaugh JF, Wang YJ, Schöneich C (2017) Photodegradation pathways of protein disulfides: human growth hormone. Pharm Res 34:2756-2778. https://doi.org/10.1007/s11095-017-2256-6

Straub JA, Akiyama A, Parmar P, Musso GF (1995) Chemical pathways of degradation of the bradykinin analog, Rmp-7. Pharm Res 12:305-308. https://doi.org/10.1023/a:1016203731682

Suzuki K, Sasaki Y, Endo N, Mihara Y (1981) Acetic acid-catalyzed diketopiperazine synthesis. Chem Pharm Bull 29:233-237

Sysak PK, Foote CS, Ching TY (1977) Chemistry of singlet oxygen. 25. Photooxygenation of methionine. Photochem Photobiol 26:19-27. https://doi.org/10.1111/j.1751-1097.1977.tb07443.x

Tamba M, Torreggiani A, Tubertini O (1995) Thiyl-radicals and thiylperoxyl radicals produced from the irradiation of antioxidant thiol compounds. Radiat Phys Chem 46:569-574. https://doi. org/10.1016/0969-806x

Tassin JD, Borkman RF (1980) The photolysis rates of some dipeptides and tripeptides of tryptophan. Photochem Photobiol 32:577-585. https://doi.org/10.1111/j.1751-1097.1980.tb04025.x

Terral G, Beck A, Cianferani S (2016) Insights from native mass spectrometry and ion mobility-mass spectrometry for antibody and antibody-based product characterization. J Chromatogr B Analyt Technol Biomed Life Sci 1032:79-90. https://doi.org/10.1016/j. jchromb.2016.03.044 
Tomita M, Irie M, Ukita T (1968) Sensitized photooxidation of $N$-benzoyl histidine. Tetrahedron Lett 9:4933-4936

Torosantucci R, Mozziconacci O, Sharov V, Schöneich C, Jiskoot W (2012) Chemical modifications in aggregates of recombinant human insulin induced by metal-catalyzed oxidation: covalent cross-linking via Michael addition to tyrosine oxidation products. Pharm Res 29:2276-2293. https://doi.org/10.1007/s1109 5-012-0755-Z

Torosantucci R, Sharov VS, van Beers M, Brinks V, Schöneich C, Jiskoot W (2013) Identification of oxidation sites and covalent cross-links in metal catalyzed oxidized interferon beta-1a: potential implications for protein aggregation and immunogenicity. Mol Pharm 10:2311-2322. https://doi.org/10.1021/mp300665u

Torosantucci R, Schöneich C, Jiskoot W (2014) Oxidation of therapeutic proteins and peptides: structural and biological consequences. Pharm Res 31:541-553. https://doi.org/10.1007/s1109 5-013-1199-9

Trinder PK, Maeurer MJ, Stoerkel SS, Loos M (1997) Altered (oxidized) $\mathrm{C} 1 \mathrm{q}$ induces a rheumatoid arthritis-like destructive and chronic inflammation in joint structures in arthritis-susceptible rats. Clin Immunol Immunopathol 82:149-156. https://doi. org/10.1006/clin.1996.4293

Tsybin YO et al (2011) Structural analysis of intact monoclonal antibodies by electron transfer dissociation mass spectrometry. Anal Chem 83:8919-8927. https://doi.org/10.1021/ac201293m

Tyler-Cross R, Schirch V (1991) Effects of amino-acid sequence, buffers, and ionic strength on the rate and mechanism of deamidation of asparagine residues in small peptides. J Biol Chem 266:22549-22556

van der Burgt YEM et al (2019) Structural analysis of monoclonal antibodies by ultrahigh resolution MALDI in-source decay FTICR mass spectrometry. Anal Chem 91:2079-2085. https://doi. org/10.1021/acs.analchem.8b04515

Vlasak J et al (2009) Identification and characterization of asparagine deamidation in the light chain CDR1 of a humanized IgG1 antibody. Anal Biochem 392:145-154. https://doi.org/10.1016/j. ab.2009.05.043

von Pawel-Rammingen U, Johansson BP, Bjorck L (2002) IdeS, a novel streptococcal cysteine proteinase with unique specificity for immunoglobulin G. EMBO J 21:1607-1615. https://doi. org/10.1093/emboj/21.7.1607

Wakankar AA, Borchardt RT, Eigenbrot C, Shia S, Wang YJ, Shire SJ, Liu JL (2007) Aspartate isomerization in the complementaritydetermining regions of two closely related monoclonal antibodies. Biochemistry 46:1534-1544. https://doi.org/10.1021/bi061 $500 \mathrm{t}$

Wang W (1999) Instability, stabilization, and formulation of liquid protein pharmaceuticals. Int J Pharm 185:129-188

Wang W, Singh S, Zeng DL, King K, Nema S (2007) Antibody structure, instability, and formulation. J Pharm Sci 96:1-26. https:// doi.org/10.1002/jps.20727

Wang Y, Lu Q, Wu SL, Karger BL, Hancock WS (2011a) Characterization and comparison of disulfide linkages and scrambling patterns in therapeutic monoclonal antibodies: using LC-MS with electron transfer dissociation. Anal Chem 83:3133-3140. https ://doi.org/10.1021/ac200128d

Wang WR et al (2011b) Impact of methionine oxidation in human IgG1 $\mathrm{Fc}$ on serum half-life of monoclonal antibodies. Mol Immunol 48:860-866. https://doi.org/10.1016/j.molimm.2010.12.009

Wardman P, Vonsonntag C (1995) Kinetic factors that control the fate of thiyl radicals in cells. Method Enzymol 251:31-45. https:// doi.org/10.1016/0076-6879(95)51108-3

Wei ZP et al (2007) Identification of a single tryptophan residue as critical for binding activity in a humanized monoclonal antibody against respiratory syncytial virus. Anal Chem 79:2797-2805. https://doi.org/10.1021/ac062311j
Winterbourn CC, Parsons-Mair HN, Gebicki S, Gebicki JM, Davies MJ (2004) Requirements for superoxide-dependent tyrosine hydroperoxide formation in peptides. Biochem J 381:241-248. https:// doi.org/10.1042/BJ20040259

Wisniewski K, Finnman J, Flipo M, Galyean R, Schteingart CD (2013) On the mechanism of degradation of oxytocin and its analogues in aqueous solution. Biopolymers 100:408-421. https://doi. org/10.1002/bip.22260

Wohlschlager T et al (2018) Native mass spectrometry combined with enzymatic dissection unravels glycoform heterogeneity of biopharmaceuticals. Nat Commun 9:1713. https://doi.org/10.1038/ s41467-018-04061-7

Wright A, Bubb WA, Hawkins CL, Davies MJ (2002) Singlet oxygen-mediated protein oxidation: evidence for the formation of reactive side chain peroxides on tyrosine residues. Photochem Photobiol 76:35-46

Wu LC, Chen F, Lee SL, Raw A, Yu LX (2017) Building parity between brand and generic peptide products: regulatory and scientific considerations for quality of synthetic peptides. Int J Pharm 518:320-334. https://doi.org/10.1016/j.ijpha rm.2016.12.051

Xie M, Vander Velde D, Morton M, Borchardt RT, Schowen RL (1996) $\mathrm{pH}$-Induced change in the rate-determining step for the hydrolysis of the Asp/Asn-derived cyclic-imide intermediate in protein degradation. J Am Chem Soc 118:8955-8956

Xu CF, Chen Y, Yi L, Brantley T, Stanley B, Sosic Z, Zang L (2017) Discovery and characterization of histidine oxidation initiated cross-links in an IgG1 monoclonal antibody. Anal Chem 89:7915-7923. https://doi.org/10.1021/acs.analchem.7b00860

Yang J, Wang S, Liu J, Raghani A (2007) Determination of tryptophan oxidation of monoclonal antibody by reversed phase high performance liquid chromatography. J Chromatogr A 1156:174-182. https://doi.org/10.1016/j.chroma.2007.01.140

Yashiro H, White RC, Yurkovskaya AV, Forbes MD (2005) Methionine radical cation: structural studies as a function of $\mathrm{pH}$ using $\mathrm{X}$ - and Q-band time-resolved electron paramagnetic resonance spectroscopy. J Phys Chem A 109:5855-5864. https://doi.org/10.1021/ jp051551k

Ying T, Ju TW, Wang Y, Prabakaran P, Dimitrov DS (2014) Interactions of $\mathrm{IgG} 1 \mathrm{CH} 2$ and $\mathrm{CH} 3$ domains with FcRn. Front Immunol 5:146. https://doi.org/10.3389/fimmu.2014.00146

Yoo EM, Wims LA, Chan LA, Morrison SL (2003) Human IgG2 can form covalent dimers. J Immunol 170:3134-3138. https://doi. org/10.4049/jimmunol.170.6.3134

Yu L, Vizel A, Huff MB, Young M, Remmele RL, He B (2006) Investigation of N-terminal glutamate cyclization of recombinant monoclonal antibody in formulation development. J Pharm Biomed 42:455-463. https://doi.org/10.1016/j.jpba.2006.05.008

Zhang XJ, Foote CS, Khan SI (1993) Reactions of N-acylated indoles with singlet oxygen. J Org Chem 58:47-51. https://doi. org/10.1021/jo00053a014

Zhang H, Cui W, Gross ML (2014) Mass spectrometry for the biophysical characterization of therapeutic monoclonal antibodies. FEBS Lett 588:308-317. https://doi.org/10.1016/j.febslet.2013.11.027

Zhao F, Ghezzo-Schöneich E, Aced GI, Hong JY, Milby T, Schöneich C (1997) Metal-catalyzed oxidation of histidine in human growth hormone-mechanism, isotope effects, and inhibition by a mild denaturing alcohol. J Biol Chem 272:9019-9029

Publisher's Note Springer Nature remains neutral with regard to jurisdictional claims in published maps and institutional affiliations. 